\title{
Molecular Imaging with Reporter Genes: Has Its Promise Been Delivered?
}

\author{
Inna Serganova ${ }^{1}$ and Ronald G. Blasberg ${ }^{1-3}$
}

${ }^{l}$ Department of Neurology, Sloan Kettering Institute, Memorial Sloan Kettering Cancer Center, New York, New York; ${ }^{2}$ Department of Radiology, Memorial Hospital, Sloan Kettering Institute, Memorial Sloan Kettering Cancer Center, New York, New York; and ${ }^{3}$ Molecular Pharmacology Program, Sloan Kettering Institute, Memorial Sloan Kettering Cancer Center, New York, New York

\begin{abstract}
The first reporter systems were developed in the early 1980 s and were based on measuring the activity of an enzyme-as a surrogate measure of promoter-driven transcriptional activity-which is now known as a reporter gene system. The initial objective and application of reporter techniques was to analyze the activity of a specific promoter (namely, the expression of a gene that is under the regulation of the specific promoter that is linked to the reporter gene). This system allows visualization of specific promoter activity with great sensitivity. In general, there are 2 classes of reporter systems: constitutively expressed (always-on) reporter constructs used for cell tracking, and inducible reporter systems sensitive to endogenous signaling molecules and transcription factors that characterize specific tissues, tumors, or signaling pathways.

This review traces the development of different reporter systems, using fluorescent and bioluminescent proteins as well as radionuclide-based reporter systems. The development and application of radionuclide-based reporter systems is the focus of this review. The question at the end of the review is whether the "promise" of reporter gene imaging has been realized. What is required for moving forward with radionuclide-based reporter systems, and what is required for successful translation to clinical applications?
\end{abstract}

J Nucl Med 2019; 60:1665-1681

DOI: 10.2967/jnumed.118.220004

\section{A}

reporter cassette involves both a reporter gene and a regulatory complex. The regulatory complex includes transcriptional control components (promoters or enhancers) that can function as a constitutive (always "on") regulatory element, or the regulatory complex can be inducible (a molecular-genetic sensor), with the transcriptional regulatory elements responding to endogenous cell signals (e.g., transcription factors and transcription-regulating complexes) that can initiate and regulate reporter gene expression. A reporter system typically includes 2 components: a specific gene and regulatory complex, and a specific substrate that interacts with the gene product. The reporter gene product is a protein-either an enzyme that catalyzes a chemical reaction or a protein that fluoresces on exposure to light. Examples of commonly used reporter system pairs include radionuclide-based pairs (e.g., HSV1-tk [herpes

Received Apr. 11, 2019; revision accepted Jun. 18, 2019.

For correspondence or reprints contact: Ronald G. Blasberg, Department of Neurology, Memorial Sloan Kettering Cancer Center, 1275 York Ave., Box 52, New York, NY 10021.

Email: blasberg@neurol.mskcc.org

COPYRIGHT (C) 2019 by the Society of Nuclear Medicine and Molecular Imaging. simplex virus type 1 thymidine kinase] and ${ }^{124 / 131}$ I-FIAU [5-iodo-2' fluoro-2' deoxy-1- $\beta$-D-arabinofuranosyluracil] or ${ }^{18} \mathrm{~F}-\mathrm{FEAU}\left[2^{\prime}\right.$-deoxy$2^{\prime}-{ }^{18}$ F-fluoro-5-ethyl-1- $\beta$-D-arabinofuranosyluracil]) (1), bioluminescent pairs (e.g., firefly luciferase [FLuc] and D-luciferin) (2), and fluorescent pairs (e.g., green fluorescent protein [GFP] and activating blue light), plus sensors exploiting fluorescence resonance energy transfer between 2 mutant GFP molecules $(3,4)$. Reporter genes can be incorporated genetically into the host DNA of individual cell lines or can be used to make transgenic reporter animals. Reporter expression can be imaged and monitored by injection of a complementary probe.

Reporter gene imaging requires pretargeting (delivery) of the reporter gene cassette to the target cell or tissue by transfection or transduction. Such pretargeting is a requirement for all reporter gene imaging studies. Pretargeting of the reporter is usually achieved by several approaches, including mechanical (e.g., electroporation or microinjection), chemical (e.g., lipid or nanoparticle carriers), or biologic (e.g., viral or bacterial vectors) (5-10). In addition, reporter imaging can monitor posttranscriptional processing, modulation of reporter protein translation, protein-protein interactions, and reporter protein ubiquination. Most commonly, the reporter gene is expressed constitutively, and reporter imaging is used to track and monitor gene therapy vectors or transduced cells in the body. This strategy has been widely applied in optical imaging (11-13) and radionuclide-based imaging $(1,14-17)$ and has been applied to a lesser degree in MR imaging $(18,19)$. The history of reporter gene imaging and the major imaging technologies that have been developed for this purpose are outlined in this article, including a section on radionuclide-based clinical applications of reporter gene imaging that have been published. We also discuss the promise of reporter gene imaging and whether this promise has been delivered. We conclude with some thoughts about moving forward.

\section{REPORTER GENES: BACKGROUND AND HISTORY}

The first reporter systems were developed in the early 1980s and were based on measuring the activity of an enzyme as a surrogate measure of promoter-driven transcriptional activity (20). This strategy is now known as a reporter gene system. One of the first systems described involved chloramphenicol acetyltransferase (CAT), a bacterial enzyme that detoxifies the antibiotic chloramphenicol by acetylation (21). The assay involves linking specific promoter elements to the $C A T$ gene (reporter gene), transfecting the reporter plasmid into target cells, adding ${ }^{14} \mathrm{C}$-chloramphenicol to the target cell medium, and assaying the extract for acetylated versus nonacetylated ${ }^{14} \mathrm{C}$-chloramphenicol radioactivity (accomplished using a TLC plate to separate the 2 radiolabeled moieties). There was no visualization of cells or tissue in this original assay. 
The ability to visualize reporter activity was originally developed by Richard Jefferson during his PhD tenure in the early 1980s. The reporter system he developed was based on $\beta$-glucuronidase (GUS), an enzyme from the bacterium Escherichia coli, that is encoded by the GUS gene $(22,23)$. This enzyme, when incubated with specific colorless glucuronides or nonfluorescent substrates, metabolizes them into colored or fluorescent products. Several different glucuronides can be used as substrates for GUS, depending on the visual system being used in the assay (e.g., histochemical, spectrophotometric, or fluorometric). Jefferson adapted this histochemical technique for use in plants because there is no detectable GUS activity in higher plants and many bacteria, resulting in a very low or no background. Thousands of labs have subsequently used GUS reporter systems in the study of plant and agriculture-focused biology (23).

A similar system ( $\beta$-galactosidase $[\beta$-gal]) to visualize reporter activity in eukaryotic cells and animals was developed shortly after the GUS system. The lacZ gene, which encodes the $E$. coli glycoside hydrolase, $\beta$-gal, has been extensively used as a reporter gene to study numerous living systems (ranging from bacteria and yeast (24) to cultured cells from diverse species of mammals (25$29)$, including mice $(30,31)$ ). Four main assays for biochemical detection of $\beta$-gal have been used. For cell extracts, spectrophotometric and fluorometric assays have been used, by which colorless compounds are converted by $\beta$-gal in the reporter-transduced cell to deeply colored products that can be measured using optical techniques. For intact cells, colorless 5-bromo-4-chloro-3-indolyl3-o-galactoside is used as the substrate, which changes to a deep blue color after conversion by the $\beta$-gal enzyme and allows visualization of $\beta$-gal reporter gene expression at the cellular and subcellular levels using standard microscopy. Although the histologic $\beta$-gal reporter imaging system has been most widely used, a fluorescence-activated cell sorting-based $\beta$-gal assay using fluorescein-di- $\beta$-D-galactopyranoside has been developed that provides the ability to sort and analyze cells based on the level of $\beta$-gal reporter expression. The fluorescence-activated cell sorting assay is both quantitative and extremely sensitive ( $\sim 20$ times more sensitive than $\beta$-gal histochemistry).

The objective and application of the reporter techniques were to analyze the activity of a specific promoter, namely the expression of a gene that is under the regulation of the specific promoter linked to the reporter gene. This allows visualization of specific promoter activity with great sensitivity in different tissues and provides a quantitative measurement of reporter activity. The advantage of the $\beta$-gal reporter system was that it could quantitatively interrogate the activity of specific promoters and visualize reporter activity at cellular and subcellular levels in different tissues using standard microscopy.

Subsequently, fluorescent, bioluminescent, and radionuclide-based reporter systems were developed to facilitate reporter imaging in animals and humans. An example of a typical reporter system is shown in Figure 1.

\section{NOTEWORTHY}

- "Constitutive" reporters are used for tracking cells.

- "Inducible" reporters are used for monitoring biological processes.

- Radionuclide-based reporters can be used in clinical applications.

- Radionuclide-based reporter imaging is currently expensive. - Reporter imaging has yet to deliver its full promise.

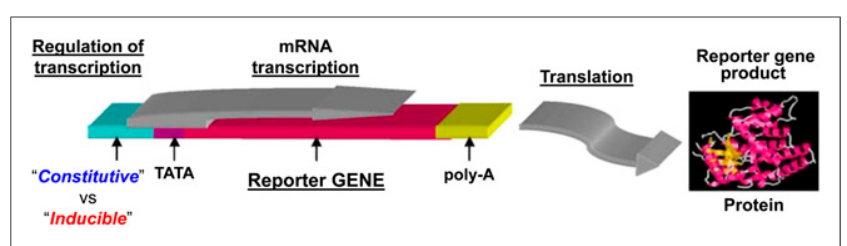

FIGURE 1. The first reporter gene systems with constitutive or inducible regulatory elements, based on measuring activity of the enzyme chloramphenicol acetyltransferase and visualizing reporter activity. Reporter systems can be placed under constitutive or inducible promoters. Constitutive promoters such as CMV, elongation factor $1 \mathrm{a}$, and others are always "on." Inducible promoters are activated by specific transcriptional factors and can function as endogenous molecular-genetic sensors. $\mathrm{mRNA}=$ messenger RNA; poly-A = the addition of a poly tail to mRNA; TATA box-DNA sequence in the core promoter region.

\section{FLUORESCENT PROTEINS}

GFP was first isolated from the jellyfish Aequorea victoria in 1960 (32) and has rapidly become one of the most widely studied and exploited proteins in biochemistry and cell biology $(33,34)$. This popularity is due to its ability to generate a highly visible, efficiently emitting internal fluorophore. GFP has become well established as a reporter of gene expression and protein targeting in intact cells and organisms. In addition to the use of GFP as a tag and as an active indicator of cellular physiology (35), mutagenesis and engineering of the GFP protein made it particularly effective for fluorescence resonance energy transfer. Five basic classes of useful GFP mutants (e.g., blue, cyan, sapphire, and yellow fluorescent proteins) have been described for fluorescence resonance energy transfer applications different in relative absorption or fluorescence brightness $(4,36)$.

One of the first applications of GFP was to detect gene expression in vivo $(37,38)$. GFP's independence from enzymatic substrates was particularly useful in intact transgenic embryos and animals (39-43) and for monitoring the effectiveness of gene transfer $(44,45)$. However, GFP reporter systems are less sensitive than the enzymebased reporter systems and require strong promoters to drive sufficient expression for detection, particularly in mammalian cells and in small-animal systems. Most published reports using GFP or enhanced GFPs have used constitutive promoters (46) or strong exogenous regulators such as the tetracycline transactivator system (47) rather than native genetic response elements (promoters) modulated by endogenous signals.

The sensitivity of the GFP reporter system is limited by its lack of amplification. Each GFP molecule produced by the reporter system produces only one fluorophore. It has been estimated that a $1 \mu \mathrm{M}$ concentration of well-folded wild-type GFP molecules is required to equal the endogenous autofluorescence of a typical mammalian cell (48). Mutant (enhanced) GFPs with improved extinction coefficients improve this detection limit by 6- to 10-fold (49). Rough calculations indicated that $1 \mu \mathrm{M}$ GFP is approximately $10^{7}$ copies per typical cell with a volume of approximately $1-2 \mathrm{pL}$. For comparison, the bacterial enzyme $\beta$-lactamase can be detected at levels as low as $60 \mathrm{pM}$ in single mammalian cells (50 molecules per cell) with membrane-permeant ester substrates (50). The sensitivity limit of the GFP reporter systems is limited not by the optical detection instrumentation but by cellular autofluorescence. However, if the GFP molecules are sequestered (concentrated) and localized to specific subcellular compartments, detection by highresolution microscopy can be successful $(50,51)$. 
The ability to monitor a subcellular localization of GFP led to its most successful and useful application, namely as a genetic fusion partner to host proteins (a chimeric GFP protein). Numerous studies have monitored and described the localization, trafficking, and fate of chimeric GFP fusion proteins. The gene encoding a GFP is fused in-frame with the gene encoding the endogenous protein, and the resulting chimera is expressed in the cell or organism of interest. The ideal result is a fusion protein that maintains the normal functions and localizations of the host protein but is now fluorescent. However, not all fusions are successful, and the failures are rarely published $(51,52)$.

\section{BIOLUMINESCENT PROTEINS}

Bioluminescence imaging (BLI) involves a technology that generates light emitted by an enzyme-substrate catalyzed chemical reaction. Unlike fluorescence or phosphorescence imaging, BLI does not require incident light and thereby provides a very low background signal and avoids phototoxicity. Although the total amount of light emitted from a bioluminescent reaction is typically small and not detectable by the human eye, an ultrasensitive charge-coupled-device camera can image bioluminescence from an external vantage point, including photons emitted from tissue or an organ in a small animal (e.g., mice) (53). The past 20 years have witnessed a significant increase of BLI in basic research, drug development, and therapy management, despite being relegated to mostly preclinical biomedical research (54).

BLI using FLuc had its origin in the late 1980s (55-59) and was used as a reporter system to study the effect of $E$. coli gene functions and a novel circadian phenotype based on FLuc expression in transgenic plants (57). There are 3 main classes of luminescent genes currently used in BLI reporter systems. The first of these, the FLuc and click beetle luciferases, are green and red luciferases from the North American firefly and the click beetle, respectively. Both FLuc and click beetle luciferase use D-luciferin as a substrate and require adenosine triphosphate, $\mathrm{Mg}^{++}$, and $\mathrm{O}_{2}$ as cofactors (12). Other luciferases, including emerald luciferase and stable red luciferase, also use D-luciferin as their substrate. However, despite this common substrate, these luciferases emit light at different wavelengths. The second main class of luminescent genes are the Renilla and Gaussia luciferases (from the sea pansy and a marine copepod, Gaussia princeps, respectively), in which coelenterazine is used as a substrate and $\mathrm{O}_{2}$ is a required cofactor. Both Renilla and Gaussia luciferases are adenosine triphosphateindependent. Gaussia luciferase (unless membrane-anchored (60) and other marine luciferases are secreted and can allow the BLI without cell lysis. More recently, Vargula and Cyridina luciferases and their substrate vargulin have been described (59,61-63). They were developed from marine ostracods-Vargula hilgendorfii and Cyridina noctiluca, respectively-and each has specific advantages (64). The third main class of luminescent genes are the bacterial luciferases (lux operon) from bacteria such as Photorhabdus luminescens and Vibrio fischeri, which include $\operatorname{lu} A B$ genes encoding heterodimeric luciferases (lux operon). The luxCDE genes can encode a fatty acid synthetase/reductase complex that generates a long-chain fatty aldehyde substrate from endogenous intracellular metabolites (65).

All luciferases require the injection of a specific luciferase substrate (e.g., D-luciferin, coelenterazine, or vargulin) into the medium or animal before imaging, and the required cofactors must be present for optimal photon emission. The bacterial luciferases are an exception, as they encode the enzymes through the lux operon required for endogenous substrate biosynthesis. Luciferases have peak emissions ranging from blue to red (e.g., 400-620 nm). However, the emission bandwidths are broad and significantly overlap in the yellow-green region (66). Given the increasingly wide use of BLI in biologic studies, new luciferase genes and mutated variants continue to be developed, as well as structural modifications of the luciferases and their substrates, to enhance photon emission, provide a wider range of photon emissions for multispectral studies, and red-shift the photon emissions $(>620 \mathrm{nM})$ to enhance their penetration in biologic tissue and small-animal models.

Luciferase-based reporter systems have been used to study detection of cancer cells and assessment of tumor growth (67-69), lymphocyte trafficking in vivo (70-72), the efficacy of immunebased cell therapies in lymphoma (73), and imaging of ligand receptor binding using luciferase complementation (74). Bacterial luciferases were successfully used for the imaging of bacterial infection of human cells (75). Marine luciferases using coelenterazine as FLuc were used to track delivery of therapeutic genes or for bioluminescence resonance energy transfer assays to detect tumor metastases (76). Many excellent studies and reviews of BLI have been published $(54,62,77-82)$. Only a few are mentioned and referenced in this article.

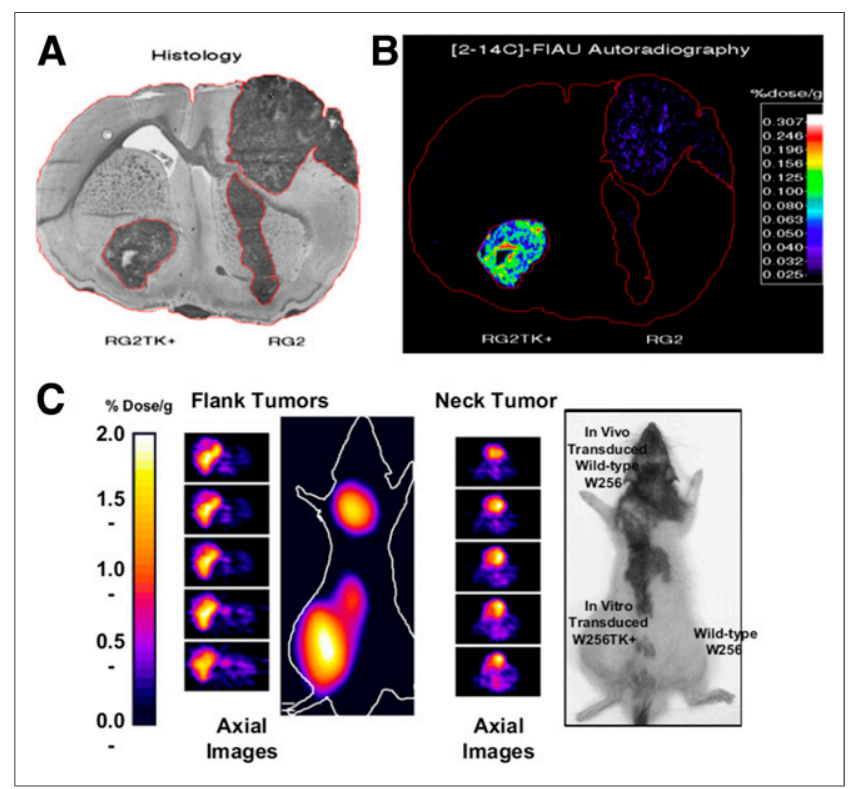

FIGURE 2. Histologic (A) and autoradiographic (B) images of HSV1-tk expression in RG2TK-positive rat brain tumor with stably expressed HSV1tk in left hemisphere and wild-type (nontransduced) RG2 tumor in right hemisphere. Both tumors are clearly seen in toluidine blue-stained histologic section. Autoradiographic imaging was performed $24 \mathrm{~h}$ after intravenous administration of ${ }^{14} \mathrm{C}$-FIAU. RG2TK-positive tumor is clearly visualized in autoradiographic image, whereas RG2 tumor is barely detectable. (C) PET imaging of HSV1-tk expression. Three tumors were generated in rnu rats: W256TK-positive (positive control) tumor in left flank and 2 wildtype W256 tumors in dorsum of neck (test) and right flank (negative control). Neck tumor was inoculated with $10^{6} \mathrm{gp}$-STK-A2 vector-producer cells (retroviral titer, $10^{6}-10^{7} \mathrm{cfu} / \mathrm{mL}$ ) to induce HSV1-tk transduction of wild-type tumor in vivo. Fourteen days after inoculation, ${ }^{124}$ I-FIAU $(925 \mathrm{kBq})$ was injected intravenously. PET was performed $30 \mathrm{~h}$ after injection. Radioactivity is clearly localized in left flank tumor and neck tumor but is only at low background level in right flank tumor (C). (Adapted with permission of (1).) 


\section{RADIONUCLIDE-BASED REPORTER GENE IMAGING}

Radionuclide-based imaging is founded on the radiotracer principle, which was first described by George de Hevesy in a 1935 letter published in Nature, using ${ }^{32} \mathrm{P}$ for the study of phosphorus metabolism (83). He was awarded the Nobel Prize in chemistry in 1943 (84). The principle forms the basis for the use of radionuclides to investigate the behavior and function of stable atoms and molecules and for the ability of radiopharmaceuticals to participate in biologic processes without being altered or perturbed. The tracer technique was later adapted for many applications in physiology and biochemistry, as well as in functional diagnosis and in nuclear medicine and molecular imaging. A unique feature of radionuclide-based reporter imaging is the potential for rapid translation into clinical studies, using a well-established nuclear medicine clinical infrastructure. Radionuclide-based reporter imaging was initiated in the mid-1990s, largely in the Blasberg and Gambhir lab, the Herschman lab, and the Phelps lab (Fig. 2) (1,14-16,85-92). HSV1-tk was initially used as the reporter gene, because the HSV1-tk enzyme would selectively phosphorylate specific radiolabeled substrates. The phosphorylated substrates would become trapped in the cell (similar to the phosphorylation and subsequent trapping of ${ }^{18}$ F-FDG by endogenous hexokinase), resulting in a reporter-based, enzymatic amplification of the radioactive signal. The radiolabeled substrates used in these initial studies included ${ }^{14} \mathrm{C}$ - and ${ }^{124 / 131} \mathrm{I}$-FIAU and $8-{ }^{3} \mathrm{H}$ - or $8-{ }^{14} \mathrm{C}$-ganciclovir and $\left[8{ }^{18} \mathrm{~F}\right]$-fluoroganciclovir (Fig. 3A). Later, Dr. Gambhir in the Hershman Lab developed a mutant HSV1-tk reporter gene (HSV1sr39tk) $(16,91)$ and combined it with radiolabeled penciclovir analogs (e.g., 8- ${ }^{18}$ F-fluoropenciclovir) (93) and 9-[4-18 F-fluoro3-(hydroxymethyl)butyl]guanine $\left({ }^{18} \mathrm{~F}-\mathrm{FHBG}\right)(94,95)$, which resulted in significantly enhanced sensitivity for imaging reporter gene expression in vivo (94). The early studies of radionuclide-based reporter imaging focused on optimizing and comparing the reporter systems, both reporter genes and radiolabeled reporter substrates (Fig. 3B) (96).

The sodium iodide symporter (NIS) was used as a therapeutic gene and then as a combined imaging and therapeutic gene in the late 1990s and early 2000s (97-100). NIS-transfected cell lines and animal tumor models generated from these cells can retain variable amounts of iodide for only short periods $(5-10 \mathrm{~h})$ because there is no organification or trapping of the transported iodide (as in the thyroid gland). The high uptake and retention of iodide explains, in part, the encouraging therapeutic results reported by several groups for some, but not all, tumor models (101). The variable uptake and trapping of iodide in different NIS-transduced cell types and tumors remains largely unexplained. It has been suggested that the iodide efflux system may be less efficient or more rapidly saturated in some cell types than in others, although the exact mechanism for this difference is not known.

There are 2 classes of reporter systems for transducing cells or tissue: the first is constitutively expressed reporter constructs, and the second is inducible reporter systems sensitive to endogenous signaling molecules and transcription factors that are specific to tissues, tumors, or signaling pathways and these promoters' response to activators such as hormones, heat, drugs, and small molecules (Fig. 1) (102).

One approach to expanding the application of reporter imaging, which was studied extensively in the early 2000s by several labs, was multiple-modality reporter imaging. To implement this strategy, 2 or 3 reporter genes were incorporated into a single reporter cassette. These combinations usually included a fluorescence (e.g., GFP) or bioluminescence (e.g., FLuc) gene, as well as a radionuclide-based gene, which were incorporated into the reporter expression cassette (Fig. 4) (103-107).

The combination of reporter genes for different imaging modalities compensates for the limitations of each modality alone. For example, compared with BLI, radionuclide-based imaging is highly sensitive and quantitative, but expensive, especially in preclinical models. Similarly, radionuclide-based imaging does not have the resolution for single-cell imaging, whereas fluorescence imaging strategies are more widely applied in basic preclinical research. Optical imaging is cost-effective and sensitive for surface detection and can be used for single-cell imaging (108-110). The recent development of nanobiology offers a great range in multimodality imaging opportunities. Nanoparticles are being used as novel theranostic and drug delivery agents and are able to include reporter imaging systems (111).

The early preclinical applications of radionuclide-based reporter imaging focused on molecular biology-related reporter imaging

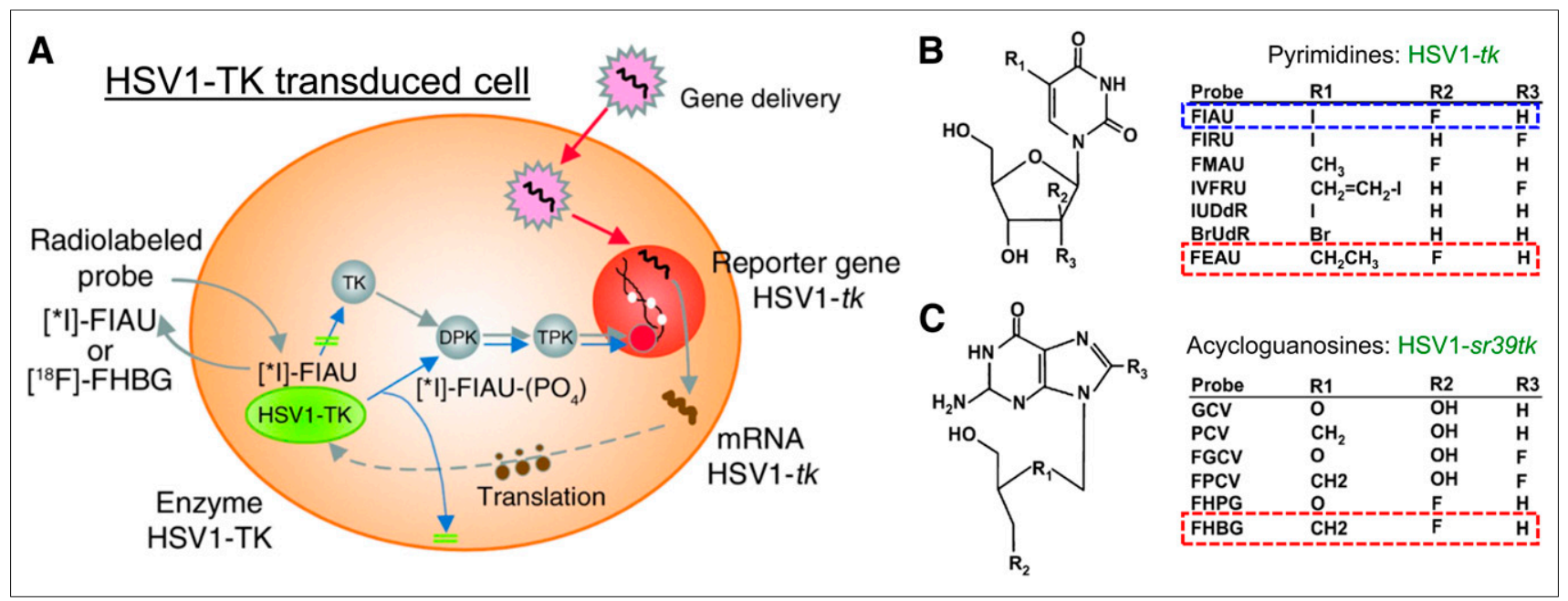

FIGURE 3. (A) HSV1-tk processing for imaging with different reporter probes $\left({ }^{124} \mathrm{I}-\right.$ or ${ }^{131} \mathrm{I}-\mathrm{FIAU}$ and $\left.{ }^{18} \mathrm{~F}-\mathrm{FHBG}\right)$. (B and $\left.\mathrm{C}\right) \mathrm{Chemical}$ structures of pyrimidine $(B)$ and acycloguanosine $(C)$ nucleoside probes. Highlighted nucleosides have been determined to be most effective imaging probes for HSV1-tk (pyrimidines) and HSV1-sr39tk (acycloguanosines). Adapted from (96). 


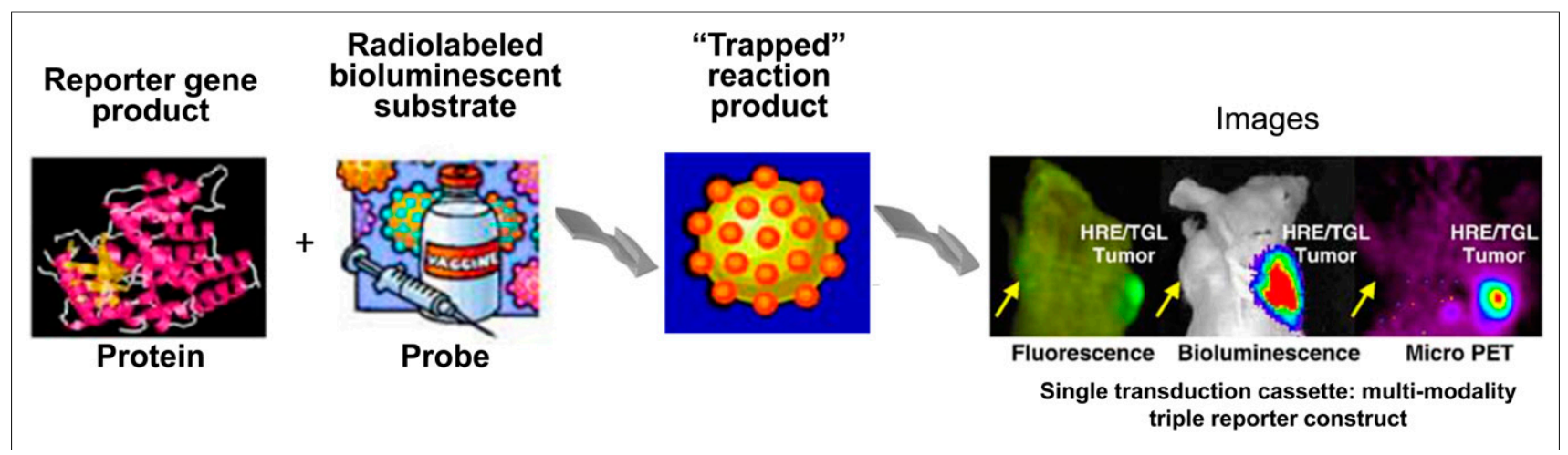

FIGURE 4. Development of fusion gene to code fusion protein for multimodality imaging. Fusion protein contains HSV1-tk for imaging with reporter probes ${ }^{124}$ I- or ${ }^{131}$ I-FIAU and ${ }^{18}$ F-FHBG; GFP component is used for fluorescence-activated cell sorting and fluorescence imaging; FLuc component is used for BLI.

studies. They included cytoplasmically retargeted HSV1-reporter gene mutants to improve imaging sensitivity (104) and were used for monitoring DNA delivery. Imaging of dihydrofolate reductase fusion gene expression (112) and imaging of gene expression from a bicistronic message $(102,113-115)$ were particularly notable developments.

Constitutive reporters are always "on," and the reporter protein is continuously expressed $(116,117)$. Constitutive reporters are usually independent of environmental and developmental factors, and they are active across species and kingdoms. Constitutive reporter systems are the most common and are largely used for monitoring the trafficking, targeting, and persistence of cells, bacteria, and viruses $(86,118-120)$. Constitutive promoters can be tissue-specific, such as the tyrosinase promoter for melanoma (121); some other promoters can be active in different tumor types, such as human telomerase reverse transcriptase promoter (122) and the progression elevated gene-3 (PEG-3) promoter (123).

Six constitutive promoters commonly used in mammalian systems include the simian virus 40 early promoter, cytomegalovirus immediateearly promoter (CMV), human ubiquitin $\mathrm{C}$ promoter (UBC), human elongation factor $1 \alpha$ promoter, mouse phosphoglycerate kinase 1 promoter (PGK1), and chicken $\beta$-actin promoter $(\mathrm{EF} 1 \alpha)$ coupled with CMV early enhancer (CAG promoter) (124). The choice of which promoter to use is based mostly on the availability of a promoter. However, the suitability of the promoter for a particular experiment needs to be carefully considered, since there is some variability in promoter effectiveness from cell type to cell type. For example, the CMV promoter is the most variable, being very strong in some cell types (e.g., 293T) and rather weak in others (e.g., mesenchymal stem cells). This variability is consistent with the silencing of this promoter in some cells (125).

\section{Imaging the Trafficking, Localization, and Persistence of Reporter-Transduced Organisms and Cells}

Noninvasive, in vivo tracking of lymphocytes dates back to the early 1970s, when the first experiments were performed after extracorporeal direct labeling of lymphocytes $(126,127)$ using various metallic radioisotopes (e.g., ${ }^{111} \mathrm{In},{ }^{67} \mathrm{Co},{ }^{64} \mathrm{Cu},{ }^{51} \mathrm{Cr}$, and ${ }^{99 \mathrm{~m} T c)}(126-130)$. However, there are several problems associated with ex vivo labeling, mostly related to the low level of radioactivity per cell and the exposure of cells to higher doses of radioactivity during labeling, which can affect T-cell function. Stable genetic labeling of lymphocytes with reporter genes avoids the temporal limitations of in vitro radiolabeling or magnetic labeling of cells and can assist long-term study for cell survival, proliferation, and activation of immune cells. Retrovirus-mediated transduction has proven to be one of the most effective methods to deliver transgenes into $\mathrm{T}$ cells, resulting in high levels of sustained transgene expression $(131,132)$. This approach was used to deliver transgenes for detection of long-term circulation of EpsteinBarr virus-specific cytotoxic donor-derived $\mathrm{T}$ cells in patients treated for post-bone-marrow-transplantation Epstein-Barr virusinduced lymphoproliferative diseases (133-135). Genetic labeling of lymphocytes can also be achieved with the luciferase reporter gene $(136,137)$ and with the fusion reporter genes (e.g., HSV1-tk/ GFP [TKGFP]) (138). Sequential imaging over $15 \mathrm{~d}$ after T-cell injection permitted long-term monitoring of the TKGFP-transduced cells and demonstrated tumor-specific migration and targeting of the CD8-positive cytotoxic T-lymphocyte (CTLs). A transgenic mouse model that uses T-cell-specific luciferase bioluminescence for tracking T-cell homing and migration dynamics in vivo was developed and provided important insights and advantages from tracking T-cell responses in vivo (139). Migration of dendritic cells into lymph nodes was visualized with BLI and ${ }^{124}$ I PET/CT imaging modalities using dendritic cells expressing FLuc and NIS reporter genes (140). A similar approach was used to detect the migration of macrophages toward inflammation at early time points (106), as well as tumor lesions (141). The HSV1-tk/PET application was used to trace human embryonic stem cells transplanted in the heart $(142,143)$. However, this labeling strategy has its own disadvantages: it is difficult to generate stably transfected cells because of the low efficiency of transfection of immune and primary stem cells, and some safety concerns have been raised (144).

In addition to constitutive promoters, cell- and tissue-specific promoters have been described and used in reporter gene imaging (145-148). For example, the radiation-responsive elements (CC(A/T) 6GG, known as CArG) were identified in the promoter of the early growth response 1 (Egr-1) gene and were used in a clinical trial to express tumor necrosis factor $\alpha$ in patients with soft-tissue sarcomas receiving radiation (149). An alternative approach used the promoter with a broad cancer specificity, making it a universal promoter for cancer cell imaging $(150,151)$. The common feature of the above promoters is that they have transcriptional regulatory elements for biomarkers found in many human cancer cells (152). For example, the PEG-3 promoter was developed and used for imaging metastasis in vivo (123). The most interesting characteristic of the PEG-3 promoter is that there is no homologous sequence in the human 


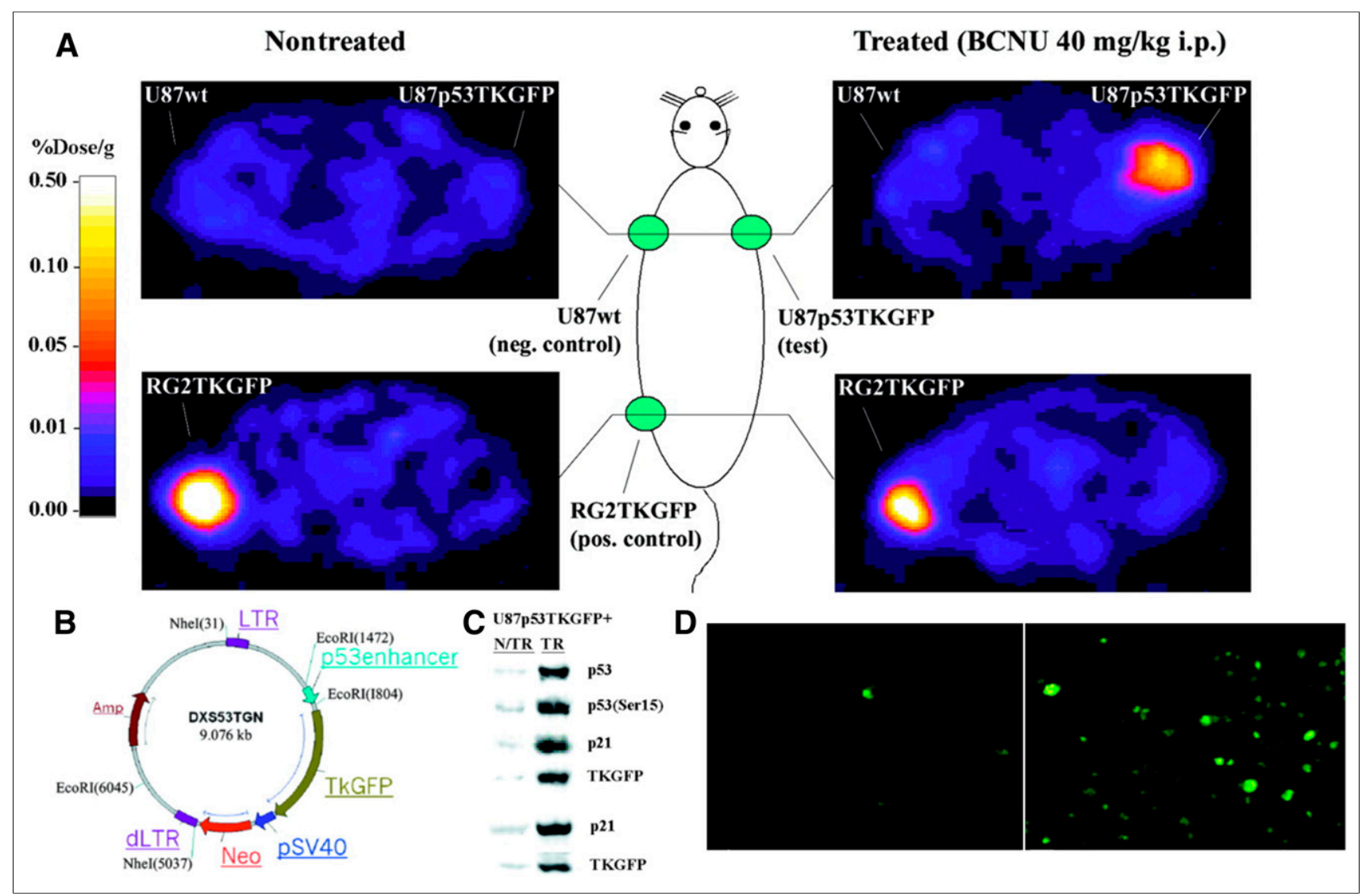

FIGURE 5. Validation of first inducible reporter system for p53 pathway in cells and tumors. (A) PET imaging of endogenous p53 activation. Transaxial PET images through shoulder (top 2 panels) and pelvis (bottom 2 panels) of 2 rats are shown. Both nontreated and treated animals had 3 subcutaneous tumor xenografts: U87p53TKGFP (test) in right shoulder, U87 wild-type (negative control) in left shoulder, and RG2TKGFP (positive control) in left thigh. Treated animal shows significant radioactivity localization in test tumor and in positive control but no radioactivity above background in negative control. (B) Structure of p53TKGFP retroviral vector with reporter system. Expression of TKGFP gene is regulated by artificial promoter containing multiple tandem repeats of p53-specific DNA-binding motif. Constitutive expression of neomycin-resistance gene (Neo) is driven by SV40 (simian virus 40 early) promoter, allowing for selection of stably transduced cells. LTR $=$ Long Terminal Repeat; dLTR $=$ deleted LTR. This vector has a mutation in the $3^{\prime} \mathrm{LTR}$ that renders the silencing of its promoter activity after duplication as $5^{\prime} \mathrm{LTR}$ during integration. Amp $=$ ampicillin; EcoRI, Nhel = are restriction enzymes that cleaves DNA. (C) U87p53TKGFP subcutaneous tumor samples assessed for levels of activated p53 (Ser15 phosphorylated), total p53 protein, p21, and TKGFP proteins by immunoblot analysis obtained from nontreated and treated rats. (D) Microscopic fluorescence images of same U87p53TKGFP subcutaneous tumor samples. (Adapted with permission of (153).)

genome. The PEG-3 promoter functions as a sensor for the cellular environment of cancer cells. Two transcription factors, activator protein 1 and polyoma enhancer activator 3, are known to be key regulators for PEG-3 promoter activity. Using BLI with FLuc and radionuclide imaging based on HSV1-tk and ${ }^{125}$ I-FIAU, the Pomper group was able to demonstrate that PEG-3 promoter drives the expression of reporters selectively in metastatic tissues (123).

\section{Imaging Signaling Pathways with Inducible Reporter Systems}

We pioneered the development of radionuclide-based imaging of transcriptional regulation of endogenous genes in living animals, by placing the reporter genes under specific cancer-upregulated promoters. Together with Juri Tjuvajev/Gelovani Tjuvajev (aka Tjuvajev), we showed that p53-dependent gene expression can be imaged in vivo by PET and by in situ fluorescence (Fig. 5) (153). A similar noninvasive imaging strategy was used for monitoring T-cell activation in vivo. We developed and assessed a novel reporter for imaging T-cell receptor-dependent nuclear factor of activated $\mathrm{T}$ cell (NFAT)-mediated activation of T cells (154). The TKGFP dual-reporter gene was used to monitor NFAT-mediated transcriptional activation in human Jurkat cells. PET imaging with ${ }^{124} \mathrm{I}-$ FIAU using the NFAT-TKGFP reporter system was sufficiently sensitive to detect T-cell activation in vivo. Instead of focusing on only the location of $\mathrm{T}$ cells, the NFAT reporter provides monitoring and a better understanding of T-cell effector functions. Subsequently, $\mathrm{T}$ cells transduced with a reporter vector containing the hybrid pGB-CMVe promoter (the granzyme B promoter [pGB]; cytomegalovirus enhancer [CMVe]) for BLI imaging was used to monitor T-cell effector function in response to tumor antigens in living mice (155).

We also developed an inducible reporter system that was sensitive to hypoxia and could be monitored by noninvasive imaging $(156,157)$. Upregulation of the hypoxia-inducible factor (HIF)-1 transcriptional factor was demonstrated and correlated with the expression of dependent downstream genes (e.g., vascular endothelial growth factor) (Fig. 6). Recently, we showed that replacing the small-animal PET reporter with optical reporters can be used to study the tumor microenvironment in murine metastatic model of breast cancer (158). These reporter systems could be used to 

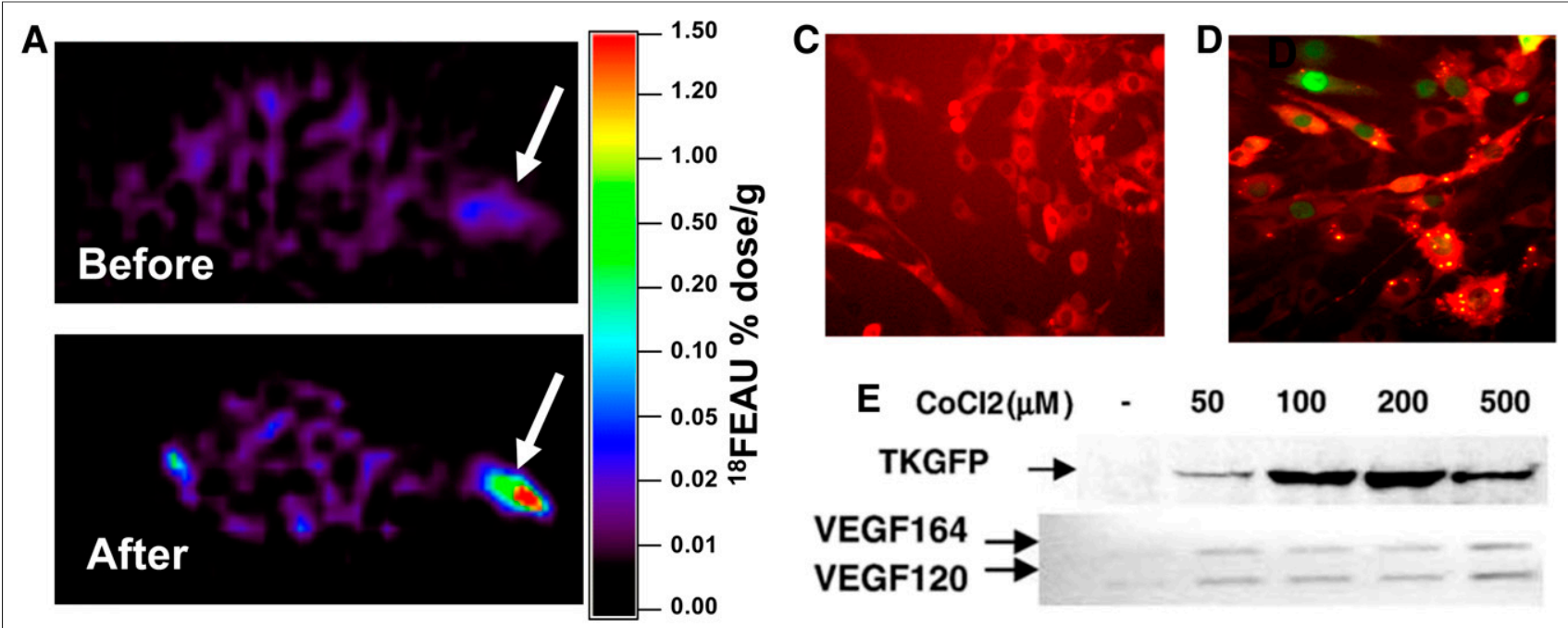

B

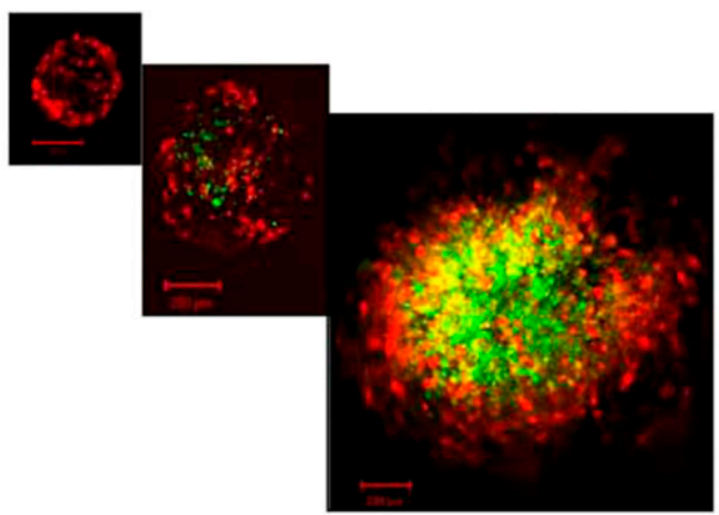

$\mathbf{F}$

Hypoxia Response Element (HRE) $\times 8$ 5' - GCCCTACGTGCTGTCTCACACAGC - 3'

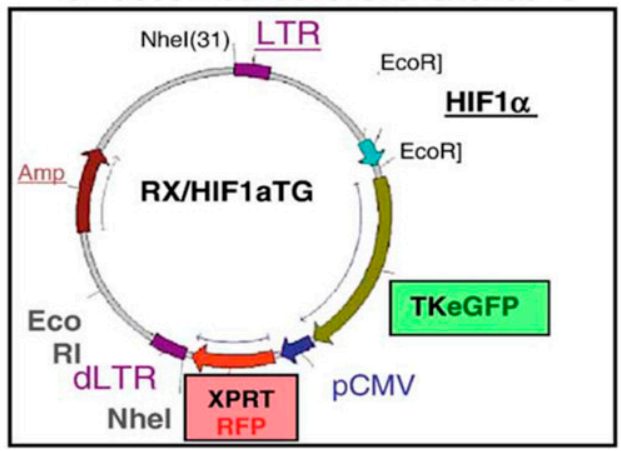

FIGURE 6. Validation of first dual-reporter system (hypoxia-inducible and constitutive reporter system in cells and tumors). (A) HIF-1 (hypoxia inducible factor 1)-mediated TKGFP expression was studied in model with subcutaneous 4C6 xenograft bilaterally in forelimbs before and after tourniquet was applied to left forelimb proximal to tumor. ${ }^{18} \mathrm{~F}$-FEAU uptake (arrows) is seen only in tourniquet-applied limb. (B) HIF-1 response in growing spheroids. (C and D) Confirmation of integrity of HIF-1 signaling pathway and reporter systems in C6 rat glioma cells before (C) and after (D) HIF-1 upregulation by $100 \mu \mathrm{M}$ of $\mathrm{CoCl}_{2}$ (hypoxia mimetic). (E) Western blotting for TKGFP and reverse-transcriptase polymerase chain reaction for VEGF164 and VEGF120, $24 \mathrm{~h}$ after exposure to different concentrations of $\mathrm{CoCl}_{2}$. (F) Structure of cis-HRE/TKGFP retroviral vector with dual-reporter systems. Expression of HSV1-tk/eGFP gene is regulated by artificial promoter containing 8 tandem repeats for HIF-1 DNA-binding motif. Constitutive expression of XPRT/dsRFP is driven by CMV promoter (pCMV), allowing for selection of stably transduced cells. (Adapted with permission of (156).)

assess the effects of radiation, new drugs, or other novel therapeutic paradigms that affect the HIF-1 signaling pathways (156-158). Similar to the nuclear factor of $\kappa$ light polypeptide gene enhancer in B-cells inhibitor, $\alpha$-FLuc fusion reporter (159), we were able to study the tightly controlled level of HIF-1 $\alpha$ protein in normal (NIH3T3 and HEK293) and glioma (U87) cells by developing 2 HIF- $1 \alpha$ chimeric reporter systems, HIF- $1 \alpha /$ FLuc and HIF- $1 \alpha$ (change in oxygen-dependent degradation domain)/FLuc. These reporter systems provided an opportunity to investigate the degradation of HIF-1 $\alpha$ in different cell lines, both in culture and in xenografts (160). In addition to the HIF-1-activated pathway, we monitored the response (activation) of the HSF1 transcription factor after treatment with the geldanamycin analog, 17-allylamino-demethoxy geldanamycin, in cells and in animals bearing xenografts transduced with human NIS (hNIS) and GFP reporter systems $(161,162)$.

The application of the 2 most widely used optical reporters, FLuc and GFP for bioluminescence and fluorescence imaging, dramatically improved the detection of bone metastases in mice in vivo and ex vivo $(67,163)$. In addition, we and others developed a noninvasive multimodality imaging approach to identify and localize metastatic cells in bones, to monitor tumor growth, and to register activation of the transforming growth factor $\beta$ pathway during metastasis (163-166).

A recent publication by the Gambhir group demonstrates that endogenous biomarkers can provide early disease detection using a cell-based in vivo sensor with high sensitivity for the early detection of cancer (167). They leveraged the M1/M2 macrophage metabolic dichotomy as the basis for developing a novel cell sensor and engineered macrophages to produce a synthetic reporter on adopting an M2 tumor-associated metabolic profile. This was achieved by coupling a reporter gene (luciferase) to activation of the arginase-1 promoter (Fig. 7). After adoptive transfer in colorectal and breast mouse tumor models, the engineered macrophages migrated to the tumors and activated arginase-1, thereby providing a bioluminescence signal that could be imaged in their animal model, as well as in blood from the tumor-bearing animal. They effectively used M2 polarization as a diagnostic surrogate for the detection of small tumors. The macrophage sensors were also able to 


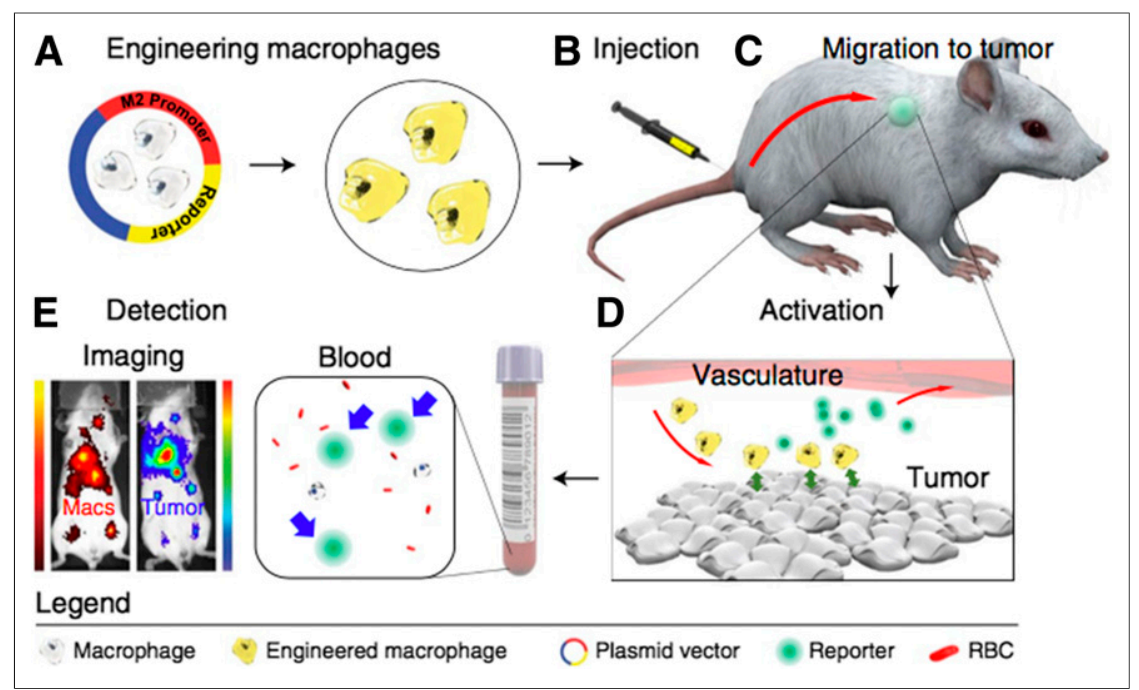

FIGURE 7. Diagnostic adoptive cell transfer. (A) Macrophages are genetically engineered to secrete synthetic biomarker on adopting tumor-associated metabolic profile. (B and $C$ ) Engineered macrophages are injected intravenously into syngeneic hosts $(B)$ and allowed to home to existing sites of disease (C). (D) Blood test can then be used to monitor for secretion of biomarker that would indicate presence of disease. (E) This system can also provide spatial information on immune cell activation with use of imageable synthetic biomarker. RBC = red blood cell; Macs = macrophages. (Reprinted with permission of (167).)

effectively track the immunologic response to inflammation in muscle and lung animal models, suggesting the potential utility of this approach in disease states other than cancer.

\section{RADIONUCLIDE-BASED HUMAN REPORTER GENE IMAGING SYSTEMS: PRECLINICAL STUDIES}

Because of the concerns related to the potential immunogenicity of reporter systems based on viral and other nonhuman genes, an effort was made to explore the potential for developing humanderived reporter genes. A selected list of human reporter systems that have been studied is presented in Table 1.

The hNIS has long been recognized as an imaging and therapeutic target in thyroid cancer $(168,169)$. After the successful cloning of hNIS (170), combined NIS gene therapy and targeted radiotherapy have been extensively studied $(171,172)$. Many publications have also explored the use of hNIS as a reporter gene in preclinical animal studies $(114,173,174)$. An impressive body of evidence has shown that the transduction of NIS and its functional expression in some nonthyroid tumors can be used for targeted radiotherapy.

For example, it was recently shown that EGFR-targeted nonviral NIS gene transfer can be used for bioimaging and therapy of disseminated colon cancer metastases (175). That study combined the reporter and therapy gene function of NIS, similar to what was proposed earlier for HSV1-tk. The authors suggest NIS gene targeting of liver metastases as a promising theranostic strategy for, first, noninvasive imaging of functional NIS expression using ${ }^{18} \mathrm{~F}$ tetrafluoroborate as a novel NIS PET tracer and, second, therapeutic application of targeted radiotherapy using ${ }^{131}$ I-iodide. Recently, ${ }^{18} \mathrm{~F}$-tetrafluoroborate, ${ }^{18} \mathrm{~F}$-fluorosulfate, and other ${ }^{18}$ F-labeled analogs have emerged as promising iodide substitutes for PET imaging. The ${ }^{18} \mathrm{~F}$-labeled iodide analogs have practical radiosynthesis and biochemical features that allow them to closely mimic iodide transport by NIS in thyroid tissues and in other NIS-expressing tissues. Unlike radioiodide, they do not undergo organification in thyroid cells and thus have the advantage of having relatively lower uptake and of exposing the normal thyroid gland to lower radiation. Initial clinical trials of ${ }^{18} \mathrm{~F}$-tetrafluoroborate have been completed in healthy humans and thyroid cancer patients (176). The excellent imaging properties of ${ }^{18} \mathrm{~F}$-tetrafluoroborate and ${ }^{18} \mathrm{~F}$ fluorosulfate for evaluation of NIS-expressing tissues indicate their bright future in PET hNIS imaging. For $\gamma$-camera and SPECT imaging, it is well known that pertechnetate is an effective iodide substitute and is less expensive than ${ }^{123} \mathrm{I}$-iodide.

Another transporter, the human norepinephrine transporter (hNET), has been studied in immunocompromised animals and shown to be an effective human reporter gene using either ${ }^{123 / 124 / 131} \mathrm{I}-$ metaiodobenzylguanidine (MIBG) or ${ }^{18} \mathrm{~F}$-meta-fluorobenzylguanidine (MFBG) (177-179). The hNET reporter and ${ }^{18} \mathrm{~F}-\mathrm{MFBG}$ compose an excellent human reporter system for potential translation into the clinic.

Two human receptors have been developed for reporter imaging: the dopamine type 2 receptor $(\mathrm{hD} 2 \mathrm{R})(180,181)$ and the somatostatin

TABLE 1

Human Reporter Gene-Imaging Agent Pairs

\begin{tabular}{|c|c|}
\hline Reporter gene & Imaging agent \\
\hline hNIS & $2123 / 124 / 131$ I-iodide, ${ }^{99 m T c}$-pertechnetate, ${ }^{18} \mathrm{~F}$-tetrafluoroborate \\
\hline hNET & 123/124/131|-MIBG, ${ }^{18}$ F-MFBG \\
\hline hSSTR2 & ${ }^{68} \mathrm{Ga}-\mathrm{DOTATOC},{ }^{68} \mathrm{Ga}-\mathrm{DOTATATE}$ \\
\hline hD2R & ${ }^{18} \mathrm{~F}-3-\left(2{ }^{\prime}-{ }^{18} \mathrm{~F}\right.$-fluoroethyl)spiperone, ${ }^{11} \mathrm{C}$-raclopride, ${ }^{18} \mathrm{~F}$-fallypride \\
\hline $\begin{array}{l}\text { Mitochondrial thymidine kinase } 2 \text { (human thymidine kinase } 2 \text {, } \\
\text { TK2-DM) }\end{array}$ & ${ }^{124} \mathrm{I}$-FIAU, ${ }^{18} \mathrm{~F}-\mathrm{FEAU},{ }^{18} \mathrm{~F}$-L-FMAU \\
\hline Deoxycytidine kinase double mutant (dCK-A100VTM) & ${ }^{124} \mathrm{I}$-FIAU, ${ }^{18} \mathrm{~F}-\mathrm{FEAU},{ }^{18} \mathrm{~F}-\mathrm{L}-\mathrm{FMAU}$ \\
\hline
\end{tabular}

${ }^{18} \mathrm{~F}-\mathrm{L}-\mathrm{FMAU}=2^{\prime}$-deoxy-2'-18 F-fluoro-5-methyl-1- $\beta$-L-arabinofuranosyluracil. 
receptor subtype 2 (hSSTR2) (182-185). What is attractive about these human reporter genes is the availability of clinically approved radiotracers for PET imaging: $3-\left(2^{\prime}-{ }^{18} \mathrm{~F}\right.$-fluoroethyl $)$ spiperone for $\mathrm{hD} 2 \mathrm{R}$ and ${ }^{68} \mathrm{Ga}$-DOTATOC or ${ }^{68} \mathrm{Ga}$-DOTATE for hSSTR2. However, there has been limited follow-up with further preclinical studies using the $\mathrm{hD} 2 \mathrm{R} 3-\left(2^{\prime}-{ }^{18} \mathrm{~F}\right.$-fluoroethyl $)$ spiperone reporter system and only slightly more with the hSSTR2 ${ }^{68} \mathrm{Ga}$-DOTATOC or ${ }^{68} \mathrm{Ga}$-DOTATE reporter system. One concern relates to receptormediated G-protein signaling in the reporter-transduced target cells, initiated in response to endogenous substrates. This concern was abrogated by successful mutation of the $\mathrm{hD} 2 \mathrm{R}$ reporter gene, resulting in uncoupling from adenylate cyclase modulation but not 3-( $2^{\prime}-{ }^{18} \mathrm{~F}$-fluoroethyl)spiperone binding and reporter function (186). Recently, a human genetic reporter, SSTR2, was successfully applied for PET imaging of whole-body T-cell distribution and antitumor dynamics using a clinically approved radiotracer. SSTR2-expressing T cells were detectable at low densities with high sensitivity and specificity (187).

We compared 4 different PET-based reporter systems (hNET, hNIS, a human deoxycytidine kinase double mutant, and HSV1-tk) for their ability to image locally injected, reporter-transduced human T cells (188). The hNET ${ }^{18} \mathrm{~F}-\mathrm{MFBG}$ reporter system was most sensitive; it could detect less than $10^{5} \mathrm{~T}$ cells $/ \mathrm{cm}^{3}$ of imaging volume. This sensitivity was primarily due to the high uptake of ${ }^{18} \mathrm{~F}-\mathrm{MFBG}$ in the transduced T cells and low background activity in the body (Fig. 8).

Mutated versions of 2 human nucleoside kinases, thymidine kinase 2 (TK2-DM) and deoxycytidine kinase (dCK-A100VTM), which use positron-emitting nucleoside analogs, have been developed $(189,190)$. A detailed comparison of PET reporter genes with corresponding PET reporter probes was performed $(191,192)$ and showed that the detection sensitivity of human PET reporter genes and PET reporter probes is comparable to or better than that of HSV1-sr39TK $/{ }^{18}$ F-FHBG.

In addition to the human reporters, prostate-specific membrane antigen (PSMA), a human transmembrane protein, has been suggested for use as an imaging-therapeutic reporter system. High expression in prostate cancer and low expression in only a few tissues (e.g., normal prostate, proximal tubules of the kidney, and brain vasculature) (193) allow imaging of tumor cells that express the cell-surface form of PSMA. The availability of numerous PSMAbinding ligands for the radiolabeling has provided broader applicability and use of PSMA reporter imaging and targeted radiotherapy for prostate cancer (194-196). The combination of tissue-restricted expression, human biocompatibility, and availability of several imaging probes supports the potential for PSMA as a theranostic reporter system (197). However, the observation that PSMA activates the phosphoinositide-3-kinase pathways creates an obstacle to the application of PSMA as the imaging gene (198), especially for T-cell tracking.

Recently, a series of publications described a new human PET reporter gene-pyruvate kinase muscle isozyme 2, with its associated radiotracer, ${ }^{18}$ F-DASA-23 (1-((2-fluoro-6- ${ }^{18}$ F-fluorophenyl) sulfonyl)-4-((4-methoxyphenyl)sulfonyl)piperazine)—as a suitable reporter gene (199-201). An advantage of this reporter system is the potential for monitoring gene therapy in the central nervous system, because ${ }^{18}$ F-DASA-23 readily crosses the blood-brain barrier. Another approach is the use of antibody-based or antibody fragment-based reporter imaging, in which the cell-surface expression of radiometal chelate-binding antibodies irreversibly captures probe molecules (202). This is a novel and promising platform for the development of reporter probe-reporter gene combinations.

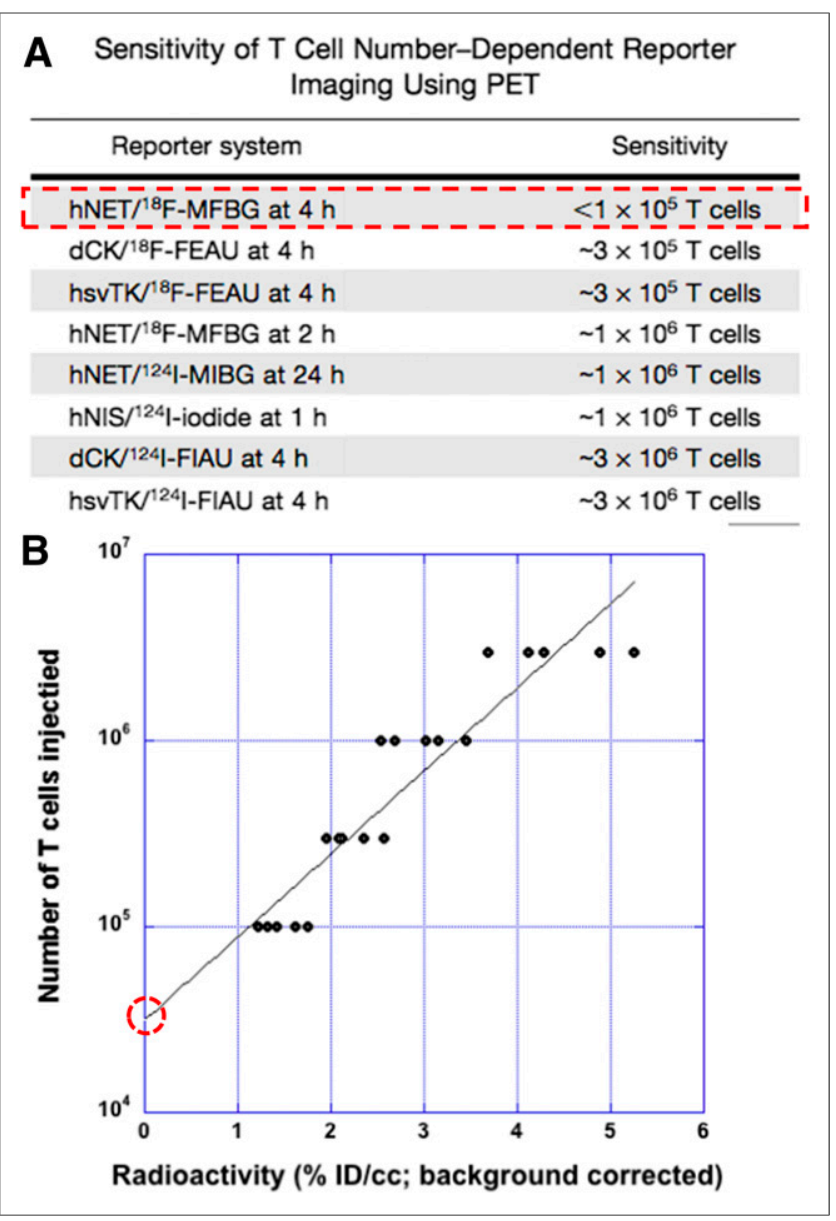

FIGURE 8. Imaging sensitivity for reporter-transduced T cells. (A) Sensitivity of hNET- ${ }^{18} \mathrm{~F}-\mathrm{MFBG}$ reporter system for imaging human $\mathrm{T}$ cells. (Reprinted from (188).) (B) hNET reporter-transduced T cells imaged $4 \mathrm{~h}$ after intravenous injection of ${ }^{18} \mathrm{~F}-\mathrm{MFBG}$. Number of imageable T cells (above background level) is more than $31,515(R=0.80)$. ID = injected dose; hsvTK = herpes simplex virus type 1 thymidine kinase (hsvTK); dCK = human deoxycytidine kinase double mutant (hdCKDM).

It is well known that the time after injection of a radiotracer has a large impact on the images and their interpretation. This is true for reporter gene imaging as well and is shown for the hNET- ${ }^{131}$ I-MIBG reporter system (Fig. 9). Washout of ${ }^{131}$ I-MIBG from the nontransduced C6 tumor occurred at a moderate rate, whereas that from the hNET-transduced C6 tumor was slow, even after correction for background radioactivity. The tumor-to-background ratio was highly time-dependent. A similar observation was made for ${ }^{124}$ I-FIAU and HSV1-tk transduced tumors; however, the background-corrected tumor radioactivity was fairly stable over $48 \mathrm{~h}$, indicating effective trapping of ${ }^{124}$ I-FIAU-phosphate in the tumor cells (203). The effect of postinjection imaging time must be considered when comparing different reporter gene imaging studies.

\section{MRI-BASED REPORTER SYSTEMS: PRECLINICAL STUDIES}

MRI reporter systems have the potential for higher resolution than can be achieved by PET, although far fewer MRI-based reporter systems have been described. The development of MRI reporter genes has focused largely on iron-accumulating proteins such as the ferritin heavy chain and the transferrin receptor 


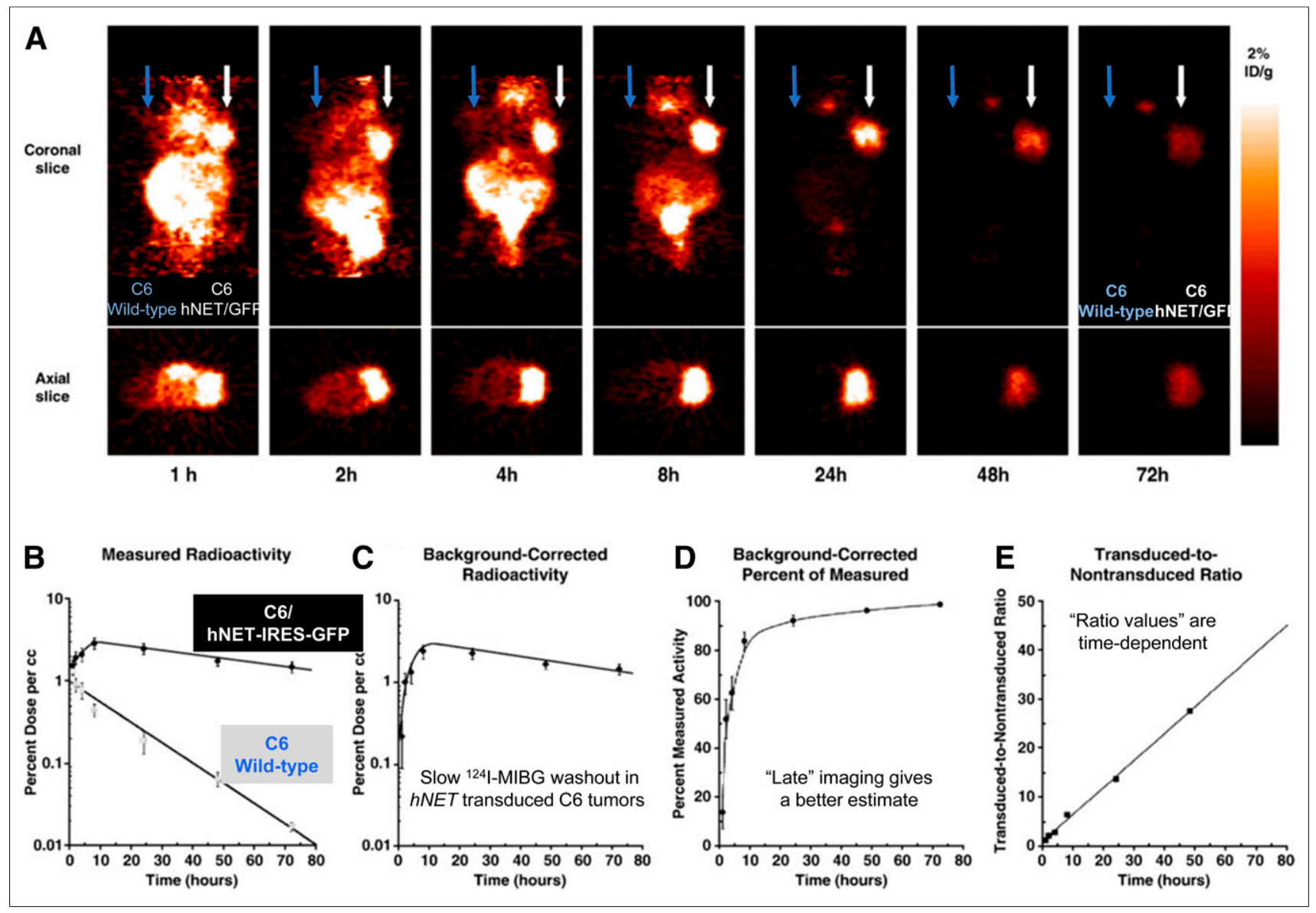

FIGURE 9. (A) Sequential small-animal PET images of ${ }^{124}$-MIBG-hNET over $72 \mathrm{~h}$ in same mouse bearing transduced C6/hNET-IRES-GFP xenograft and $\mathrm{C} 6$ wild-type xenograft in opposite shoulders, after intravenous injection of $7.4 \mathrm{MBq}(200 \mu \mathrm{Ci})$ of ${ }^{124}$ I-MIBG. (B) Time-activity profiles of ${ }^{124}$ I-MIBG accumulation. Tumor radioactivity (percentage dose/mL; maximum pixel value) was determined from sequential small-animal PET images. (C) Background-corrected radioactivity profile (transduced xenograft-to-nontransduced xenograft) for xenograft. (D) Time profile of percentage of measured radioactivity that represents background-corrected radioactivity for xenograft. (E) Time profile of transduced-to-nontransduced (background) xenograft ratio. Values are mean \pm SD $(n=10)$. ID = injected dose. (Adapted with permission of (188).)

$(204,205)$. However, this strategy results in negative contrast in the MR image and is associated with low sensitivity ( $\mathrm{mM}$ range) compared with the positive contrast in the PET image and high sensitivity (low nM) (206). Furthermore, once the reporter-transduced cells accumulate iron, they retain it for long periods, and if the cells die, the iron is taken up by macrophages, thereby negating the reversibility of iron-based reporters and precluding their use for sequential longitudinal imaging. Alternatively, positive-contrast MRI reporter genes have also been developed (207-209). Several of these positive-contrast reporters are based on a family of organic anion-transporting polypeptide proteins and apply a paramagnetic gadolinium ethoxybenzyl diethylenetriaminepentaacetic acid agent that is used in the clinic (210). A human organic anion-transporting polypeptide 1B3 reporter has been tested successfully in tumor xenografts expressing organic anion-transporting polypeptide 1B3; gadolinium ethoxybenzyl diethylenetriaminepentaacetic acid enhancement was shown on a 7-T MRI scanner (211).

\section{RADIONUCLIDE-BASED REPORTER GENE IMAGING: CLINICAL STUDIES}

Many of the initial preclinical radionuclide-based reporter imaging strategies and applications were performed with the potential for future translation to clinical studies $(15,85,94)$. One early example was HSV1-tk viral gene therapy of brain tumors, which was actively pursued in the late 1990s (212-218). In most of these studies, the expression level of HSV1-tk was not measured in the target tumor, and therefore HSV1-tk enzyme levels at the time of ganciclovir administration were unknown. Despite extensive resources, effort, and cost allocated to these clinical trials by the pharmaceutical industry, little or no clinical benefit was observed. As a result, further HSV1-tk-ganciclovir gene therapy trials in brain tumors rapidly declined (219-221). Interestingly, a PET imaging and therapeutic study (220) showed little HSV1-tk expression in the tumors before ganciclovir treatment (only 1 of 5 patients; Fig. 10A). Similarly, a SPECT study showed no detectable HSV1-tk expression (0 of 8 patients) (221).

On the basis of our preclinical studies on rats, we showed a highly significant direct relationship between FIAU uptake and ganciclovir sensitivity (inverse relationship with ganciclovir halfmaximal inhibitory concentration) that was independent of cell line or transduction vector (85). Because PET imaging of HSV1-tk gene expression in transduced tumors reflects the level of HSV1-tk gene expression, we compared the level of ${ }^{124}$ I-FIAU accumulation ( $\%$ dose/g) with an independent measure of HSV1-tk expression in the cell lines that were used to generate these tumors. Plotting the results obtained in 5 different tumors, we were able 


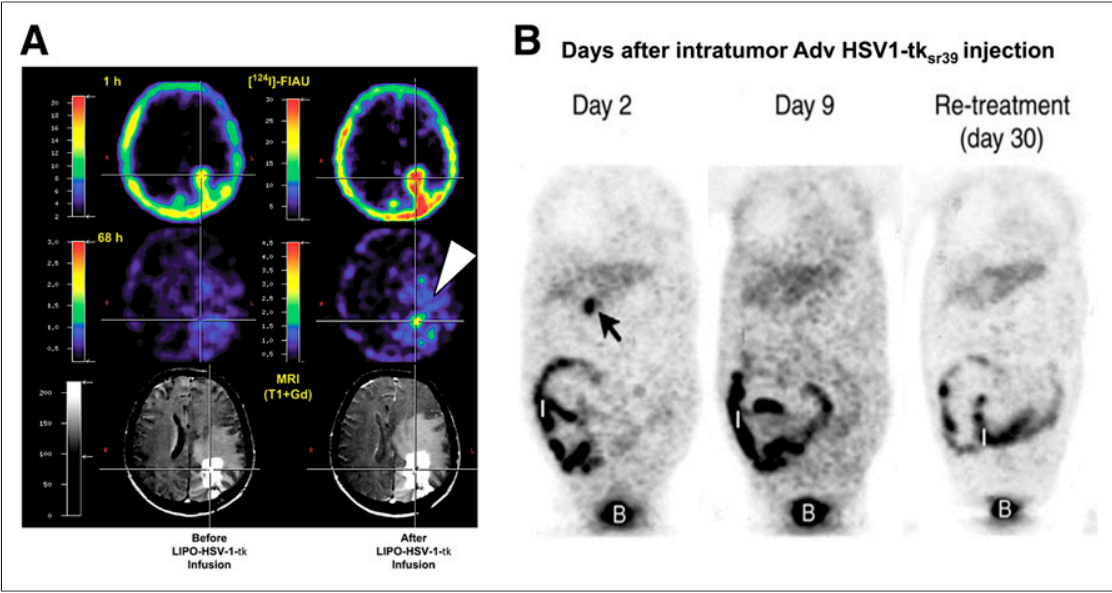

FIGURE 10. (A) HSV1-tk reporter gene imaging in GBM patient. Liposomal (LIPO) encapsulated HSV1-tk DNA was injected directly into tumor cavity. PET reporter imaging was performed (at 1 and $68 \mathrm{~h}$ after ${ }^{124} \mathrm{I}-\mathrm{FIAU}$ administration) before and after ganciclovir administration. (Reprinted with permission of (220).) (B) ${ }^{18} \mathrm{~F}-\mathrm{FHBG}$ PET of liver cancer patient treated with direct intratumor

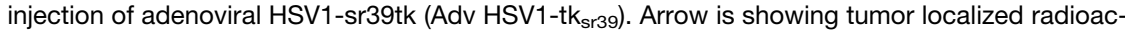
tivity seen only on day 2 , not on days 9 or 30 . Radioactive background was detected in intestine (I) and bladder (B). (Reprinted with permission of (222).)

to estimate that ${ }^{124}$ I-FIAU PET imaging should be able to detect approximately a tenth of the concentration of HSV1-tk enzyme required to achieve tumor cell lethality after a clinical dose of ganciclovir (85). This analysis is consistent with the minimal clinical benefit observed in brain tumor-HSV1-tk gene therapy trials and the lack of or minimal uptake of ${ }^{124}$ I-FIAU observed on PET imaging (220). These studies and comparisons highlight the necessity and potential of incorporating PET reporter imaging into clinical trials in which the targeting, concentration, and persistence of the therapeutic gene can be imaged and used to guide therapeutic decisions. generation vectors.
One of the more successful PET reporter imaging studies was published in 2005 (222), with ${ }^{18}$ F-FHBG being used to monitor thymidine kinase gene expression after intratumoral injection of a first-generation recombinant adenovirus expressing HSV1$t k$ in patients with hepatocellular carcinoma. This study showed that transgene expression in the tumor was dependent on the injected dose of the adenovirus (detectable in all patients who received $>10^{12}$ viral particles), whereas no specific expression of HSV1-tk could be detected in distant organs or in the surrounding cirrhotic tissue in any of the patients studied (Fig. 10B). Interestingly, $9 \mathrm{~d}$ after vector injection, no HSV1-tk expression could be observed; the authors suggested that this result could reflect elimination of HSV-tk-transduced cells after valganciclovir treatment or insufficient sensitivity of the technique for detection of low levels of HSV1-tk. Nevertheless, this study demonstrated that PET reporter imaging can help in the design of gene therapy strategies and in the clinical assessment of new-

In 2009 and 2017, the Gambhir group followed up on the Spanish study (222) with publications documenting successful noninvasive detection of CTLs genetically engineered to express HSV1-tk, after injection into the postresection tumor cavity of patients with glioma $(223,224)$. The trial involved infusion of ex vivo expanded autologous CTLs genetically engineered to express the interleukin 13 zetakine gene (which encodes a receptor protein that targets these T cells to tumor cells) and the HSVI-tk as a suicide gene and as a PET imaging reporter gene (Fig. 11). These were the first studies to document reporter-gene-based imaging of therapeutic chimeric antigen receptor $\mathrm{T}$ cells in patients. ${ }^{18} \mathrm{~F}-\mathrm{FHBG}$ PET imaging was found to be safe (223) and enabled the longitudinal imaging of T cells stably transfected with a PET reporter gene in patients. These studies also point out that ${ }^{18} \mathrm{~F}$ FHBG, which normally cannot cross the blood-brain barrier, can accumulate in gliomas with a disrupted blood-brain barrier and detect chimeric antigen receptor $\mathrm{T}$ cells that express HSV1-tk.

Although not performed on humans, repetitive PET/CT imaging with ${ }^{18} \mathrm{~F}$-FEAU was performed on 2 nonhuman primates injected with autologous polyclonal macaque $\mathrm{T}$ lymphocytes transduced with the HSV1-sr39tk reporter gene. Labeled T cells were detected after intravenous injection in discrete lymphoid organs and in sites of inflammation. This study represents a proof of principle and supports the application of ${ }^{18} \mathrm{~F}-\mathrm{FEAU}$ $\mathrm{PET} / \mathrm{CT}$ imaging for monitoring the distribution of intravenously administered HSV1sr39tk gene-transduced CTLs in humans (225). 
Similarly, a study on a pig model of myocardial infarction (2012) showed that the assessment of pluripotent stem cell survival, engraftment, and distribution was feasible. Using a constitutive NIS transgene, ${ }^{123}$ I-iodide, and SPECT, the investigators could visualize viable NIS-positive pluripotent stem cells for up to $15 \mathrm{wk}$ after cardiac injection (226). Immunohistochemistry demonstrated that stem cellderived endothelial cells contributed to revascularization. This was the first study to describe successful repeated long-term in vivo imaging of viability and tissue distribution of cellular grafts in large animals and demonstrated vascular differentiation and long-term engraftment of pluripotent stem cells in a large-animal model of myocardial infarction.

\section{THE PROMISE: HAS REPORTER GENE IMAGING DELIVERED?}

The promise was to facilitate clinical management of gene therapy and adoptive cell therapy in selected patient populations. Radionuclide-based reporter gene imaging (and molecular imaging in general) is well suited to accomplish this task, as much of the imaging infrastructure exists. Radionuclide-based imaging strategies have expanded rapidly since the mid 1990s. This growth was significantly accelerated by several National Cancer Institute-sponsored initiatives. For example, cancer imaging was identified as 1 of 6 extraordinary scientific opportunities by Richard Klausner at the National Cancer Institute in 1997-1998, and the National Cancer Institute subsequent funded a small-animal imaging resources program and an in vivo cellular and molecular imaging program. Additional support from the National Cancer Institute and the National Institutes of Health followed, including programs focused on translational molecular imaging that supported the development of novel technologies, academic-industrial partnerships, and early-phase clinical trials for first-in-human studies. These disciplines have now converged to provide a well-established foundation for exciting new research opportunities and for translation into clinical applications.

The clinical application of radionuclide-based reporter gene imaging was expected to expand as new reporter systems (both transgenes and probes) were developed and became more widely available. However, concern was raised about the potential for immune rejection of reporter-transduced cells and tissue. This concern has been increasing, particularly with respect to the incorporation of viral reporter genes into clinical studies. Several groups, including our own, focused on developing human reporter genes with complementary and well-established, clinically approved radiopharmaceuticals for PET and $\gamma$-camera imaging in patients. Nevertheless, the process of establishing humanized reporter systems and including them in clinical studies has been slow to develop. There are now 7 well-defined human reporter genes (hNIS, hNET, hD2R, hSSTR2, PSMA, human thymidine kinase 2, and human deoxycytidine kinase double mutant) with complementary radiolabeled substrates available for clinical studies (Table 1). All 7 complementary pairs (gene + probe) are good candidates for future reporter gene imaging in patients, although only the hNIS reporter system is currently moving forward in clinical trials. Importantly, these human genes are less likely to be immunogenic than are the reporter genes currently used in animals (e.g., viral thymidine kinases, luciferases, and fluorescent proteins).

A single reporter gene-reporter probe pair can be used in different reporter constructs to image many different biologic and molecular genetic processes. Once a complementary reporter pair has been approved for human studies, the major regulatory focus shifts to the particular backbone and regulatory sequence of the reporter construct and to the vector used to target reporter transduction to specific cells or tissues, both ex vivo and in vivo. Therefore, investigators are pursuing concurrent development of more efficient and safe vector systems to deliver and target transgenes to selected organs, tissues, and cells. For example, current efforts in chimeric antigen receptor T-cell therapy are focused on the design of optimal transduction plasmids (227) and constructs to help overcome a variety of potential issues within the tumor microenvironment, especially in solid tumors, which are considered to be the next generation of cancer hallmarks $(228,229)$. Ideal vectors for targeting specific organs or tumor tissues do not yet exist, although this area of human gene therapy research remains active.

Each new vector and reporter construct requires extensive and timeconsuming safety testing before it can receive regulatory approval for human administration. Nevertheless, reporter gene imaging, particularly the genetic labeling of cells, has several advantages. For example, it is possible to develop and validate reporter-based imaging strategies more rapidly and at considerably lower cost than direct imaging strategies, in which a single radiolabeled probe is developed, validated, and approved for targeting a specific epitope, because only a small number of well-characterized, validated, and approved reporter gene-reporter probe pairs need to be established.

Nevertheless, cost remains a problem. In one of the latest human reporter gene studies, costs were estimated to be approximately $\$ 200,000$ per patient (230). These included the cost of obtaining an investigational new drug approval from the Food and Drug Administration for ${ }^{18} \mathrm{~F}-\mathrm{FHBG}$, coupled with the complexity of the immunotherapy strategy in the first patient studied. Performing human reporter gene studies requires a good-manufacturing-practice-approved facility to harvest, transduce, and expand human-derived cells for reinjection into the patient (Fig. 12). Good-manufacturing-practice facilities for such activities are expensive to operate and are not widely available.

\section{REPORTER GENE IMAGING: MOVING FORWARD}

PET reporter gene imaging can provide practical and clinically useful information that identifies successful gene transduction and expression in patients undergoing gene therapy and can define the location, magnitude, and persistence of gene expression over time. One could argue that biopsies of target tissue could be performed and that imaging is not critical. However, imaging provides some clear advantages, including the ability to repeatedly assess gene expression over time, especially when multiple sequential biopsies are not feasible; the absence of any perturbation of the underlying tissue that occurs with biopsy procedures; and the ability to obtain spatial information about the entire body as well as target organs and tumors, which could be of considerable value when addressing toxicity issues.

Reporter gene imaging will continue to be limited in patients for 2 reasons. The first is the need to transduce cells and target tissues with specific reporter constructs, and the second is the absence of optimal vectors for targeting specific organs or tissues, although considerable progress has been made in the ex vivo transduction of human-derived cells $(227,231,232)$ and this continues to be an active area of research. Each new vector will require extensive and timeconsuming safety testing before Food and Drug Administration approval for human administration. However, this requirement may ease somewhat once a small number of reporter-gene-reporter-probe combinations become established for clinical use. At least 2 different reporter constructs will be required in most future applications of reporter gene imaging. The first will be a constitutive reporter that will be used to identify the site, extent, and duration of 


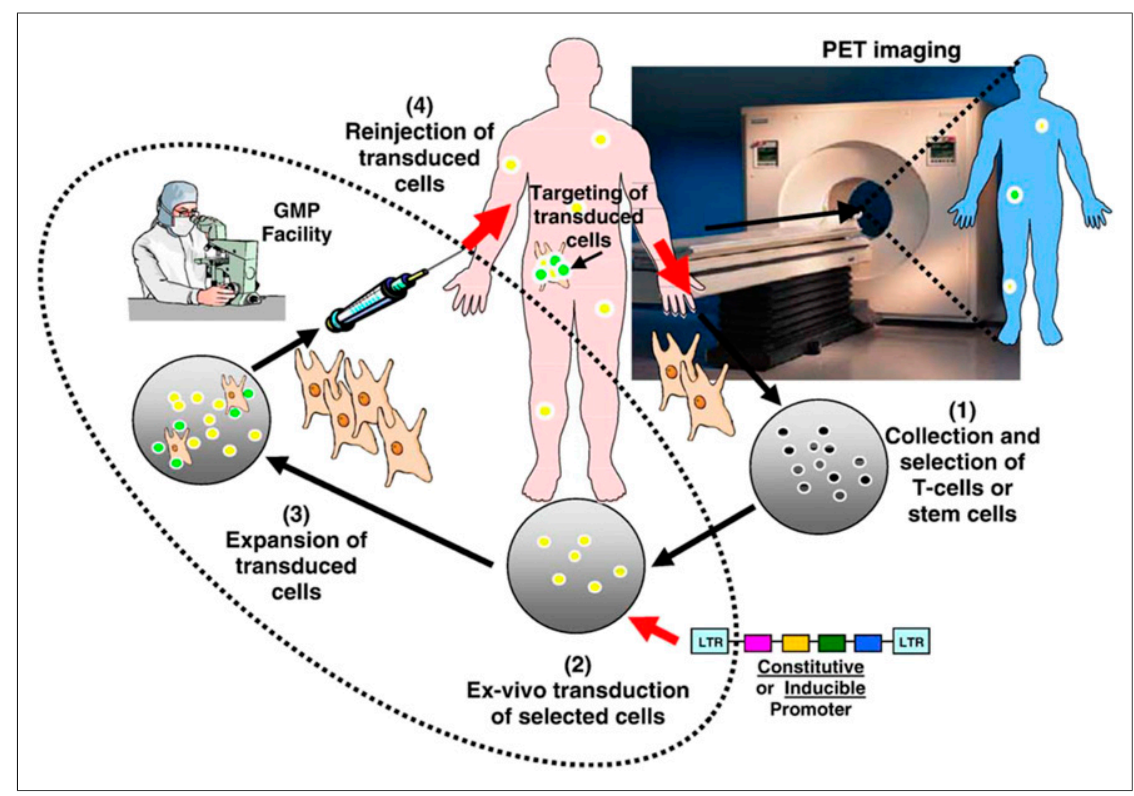

FIGURE 12. EX vivo transduction of target cells with reporter genes under constitutive or inducible promoters. Sequential enrichment and functional assessment of transduced cells in good-manufacturing-practice (GMP) facility is critical, followed by injection and imaging in living subject. LTR $=$ long terminal repeat.
hSSTR2). Nevertheless, the cost factor in implementing such studies is likely to be high, at least initially.

We remain optimistic; the tools and resources largely exist, and we should soon be able to perform gene-imaging studies on patients. The advantages and benefits of noninvasive imaging to monitor transgene expression in gene therapy protocols are obvious. By using inducible reporters, we will have the ability to visualize transcriptional and posttranscriptional regulation of endogenous target gene expression, as well as specific intracellular protein-protein interactions in patients, which will provide the opportunity for new experimental venues in patients. These venues include the potential to image the malignant phenotype of an individual patient's tumor at a molecular level and to monitor changes in the phenotype over time. The potential to image a drug's effect on a specific signal transduction pathway in an individual patient's tumor provides the opportunity to monitor treatment response at the molecular level. vector delivery and tissue transduction or to identify the distribution/trafficking, homing/targeting, and persistence of adoptively administered cells. The second will be an inducible reporter that is sensitive to endogenous transcription factors, signaling pathways, or protein-protein interactions and can monitor the biologic activity and function of the transduced cells.

We and others have suggested that the initial clinical application of an inducible reporter is likely to require transduction with a constitutive reporter as well. Such double-reporter systems would likely be used in patients as part of a gene therapy protocol or an adoptive cell-based therapy protocol, in which the patient's own cells are harvested (e.g., lymphocytes, T cells, or blood-derived progenitor cells), transduced with 2 reporter systems, expanded ex vivo, and then adoptively readministered to the patient. The inducible reporter would function as the sensor (the numerator), and the constitutive reporter would function as the normalizing term (the denominator). For example, dual-reporter gene imaging of adoptive T-cell therapy could provide a strategy for imaging T-cell activation (using an NFAT-inducible reporter), in which the NFAT reporter measurement is normalized to the local T-cell number (using a constitutive reporter). Such a dual-reporter system has the capacity for imaging T-cell trafficking, targeting, proliferation, and persistence, as well as T-cell activation $(138,154)$. These issues could be addressed quantitatively by repetitive PET imaging of the double-reporter system in the same subject over time.

An established base of reporter systems has been built (Table 1), and these systems can be used to develop several inducible and constitutive reporter constructs for human application. One key requirement for these reporter gene systems is that they be as biologically and immunologically inert as possible. Furthermore, an ideal reporter system would also incorporate a suicide component to enable the elimination of transduced cells in the event of malignant transformation. The number of reporter systems will be limited, and they are more likely to include human reporter genes for which clinically approved radiolabeled probes exist (e.g., hNIS, hNET, hD2R, and

\section{DISCLOSURE}

No potential conflict of interest relevant to this article was reported.

\section{REFERENCES}

1. Tjuvajev JG, Avril N, Oku T, et al. Imaging herpes virus thymidine kinase gene transfer and expression by positron emission tomography. Cancer Res. 1998;58: 4333-4341.

2. Contag CH, Spilman SD, Contag PR, et al. Visualizing gene expression in living mammals using a bioluminescent reporter. Photochem Photobiol. 1997;66: 523-531.

3. Llopis J, McCaffery JM, Miyawaki A, Farquhar MG, Tsien RY. Measurement of cytosolic, mitochondrial, and Golgi $\mathrm{pH}$ in single living cells with green fluorescent proteins. Proc Natl Acad Sci USA. 1998;95:6803-6808.

4. Pollok BA, Heim R. Using GFP in FRET-based applications. Trends Cell Biol. 1999;9:57-60.

5. Nonnenmacher M, Weber T. Intracellular transport of recombinant adenoassociated virus vectors. Gene Ther. 2012;19:649-658.

6. Bartel MA, Weinstein JR, Schaffer DV. Directed evolution of novel adenoassociated viruses for therapeutic gene delivery. Gene Ther. 2012;19:694-700.

7. Cronin M, Stanton RM, Francis KP, Tangney M. Bacterial vectors for imaging and cancer gene therapy: a review. Cancer Gene Ther. 2012;19:731-740.

8. Yin H, Kanasty RL, Eltoukhy AA, Vegas AJ, Dorkin JR, Anderson DG. Nonviral vectors for gene-based therapy. Nat Rev Genet. 2014;15:541-555.

9. Lam AP, Dean DA. Progress and prospects: nuclear import of nonviral vectors. Gene Ther. 2010;17:439-447.

10. Lostale-Seijo I, Montenegro J. Synthetic materials at the forefront of gene delivery. Nat Rev Chem. 2018;2:258-277.

11. Contag PR, Olomu IN, Stevenson DK, Contag CH. Bioluminescent indicators in living mammals. Nat Med. 1998;4:245-247.

12. Rehemtulla A, Stegman LD, Cardozo SJ, et al. Rapid and quantitative assessment of cancer treatment response using in vivo bioluminescence imaging. Neoplasia. 2000;2:491-495.

13. Contag CH, Jenkins D, Contag FR, Negrin RS. Use of reporter genes for optical measurements of neoplastic disease in vivo. Neoplasia. 2000;2:41-52.

14. Tjuvajev JG, Stockhammer G, Desai R, et al. Imaging the expression of transfected genes in vivo. Cancer Res. 1995;55:6126-6132.

15. Tjuvajev JG, Finn R, Watanabe K, et al. Noninvasive imaging of herpes virus thymidine kinase gene transfer and expression: a potential method for monitoring clinical gene therapy. Cancer Res. 1996;56:4087-4095. 
16. Gambhir SS, Barrio JR, Wu L, et al. Imaging of adenoviral-directed herpes simplex virus type 1 thymidine kinase reporter gene expression in mice with radiolabeled ganciclovir. J Nucl Med. 1998;39:2003-2011.

17. Gambhir SS, Barrio JR, Phelps ME, et al. Imaging adenoviral-directed reporter gene expression in living animals with positron emission tomography. Proc Natl Acad Sci USA. 1999;96:2333-2338.

18. Weissleder R, Simonova M, Bogdanova A, Bredow S, Enochs WS, Bogdanov A. MR imaging and scintigraphy of gene expression through melanin induction. Radiology. 1997;204:425-429.

19. Louie AY, Huber MM, Ahrens ET, et al. In vivo visualization of gene expression using magnetic resonance imaging. Nat Biotechnol. 2000;18:321-325.

20. Gorman CM, Merlino GT, Willingham MC, Pastan I, Howard BH. The Roussarcoma virus long terminal repeat is a strong promoter when introduced into a variety of eukaryotic cells by DNA-mediated transfection. Proc Natl Acad Sci U S A. 1982;79:6777-6781.

21. Shaw WV, Packman LC, Burleigh BD, Dell A, Morris HR, Hartley BS. Primary structure of a chloramphenicol acetyltransferase specified by $\mathrm{R}$ plasmids. Nature. 1979;282:870-872.

22. Jefferson RA, Burgess SM, Hirsh D. $\beta$-glucuronidase from Escherichia coli as a gene-fusion marker. Proc Natl Acad Sci USA. 1986;83:8447-8451.

23. Jefferson RA, Kavanagh TA, Bevan MW. GUS fusions: $\beta$-glucuronidase as a sensitive and versatile gene fusion marker in higher-plants. EMBO J. 1987;6:3901-3907.

24. Casadaban MJ, Martinezarias A, Shapira SK, Chou J. $\beta$-galactosidase gene fusions for analyzing gene-expression in Escherichia coli and yeast. Methods Enzymol. 1983;100:293-308.

25. An G, Hidaka K, Siminovitch L. Expression of bacterial $\beta$-galactosidase in animal cells. Mol Cell Biol. 1982;2:1628-1632.

26. Hall CV, Jacob PE, Ringold GM, Lee F. Expression and regulation of Escherichia coli lacZ gene fusions in mammalian cells. J Mol Appl Genet. 1983;2:101-109.

27. Nielsen DA, Chou J, MacKrell AJ, Casadaban MJ, Steiner DF. Expression of a preproinsulin-beta-galactosidase gene fusion in mammalian cells. Proc Natl Acad Sci USA. 1983;80:5198-5202.

28. MacGregor GR, Mogg AE, Burke JF, Caskey CT. Histochemical staining of clonal mammalian cell lines expressing E. coli beta galactosidase indicates heterogeneous expression of the bacterial gene. Somat Cell Mol Genet. 1987;13:253-265.

29. Nolan GP, Fiering S, Nicolas JF, Herzenberg LA. Fluorescence-activated cell analysis and sorting of viable mammalian cells based on $\beta$-D-galactosidase activity after transduction of Escherichia coli lacZ. Proc Natl Acad Sci USA. 1988;85:2603-2607.

30. Goring DR, Rossant J, Clapoff S, Breitman ML, Tsui LC. In situ detection of beta-galactosidase in lenses of transgenic mice with a gamma-crystallin/lacZ gene. Science. 1987;235:456-458.

31. Macgregor GR, Nolan GP, Fiering S, Roederer M, Herzenberg LA. Use of Escherichia coli (E. coli) lacZ (beta-galactosidase) as a reporter gene. Methods Mol Biol. 1991;7:217-235.

32. Shimomura O, Johnson FH, Saiga Y. Extraction, purification and properties of aequorin, a bioluminescent protein from the luminous hydromedusan, Aequorea. J Cell Comp Physiol. 1962;59:223-239.

33. Remington SJ. Green fluorescent protein: a perspective. Protein Sci. 2011;20: 1509-1519.

34. Chudakov DM, Lukyanov S, Lukyanov KA. Fluorescent proteins as a toolkit for in vivo imaging. Trends Biotechnol. 2005;23:605-613.

35. Llopis J, McCaffery JM, Miyawaki A, Farquhar MG, Tsien RY. Measurement of cytosolic, mitochondrial, and Golgi $\mathrm{pH}$ in single living cells with green fluorescent proteins. Proc Natl Acad Sci USA. 1998;95:6803-6808.

36. Heim R, Tsien RY. Engineering green fluorescent protein for improved brightness, longer wavelengths and fluorescence resonance energy transfer. Curr Biol. 1996;6:178-182.

37. Tsien RY. The green fluorescent protein. Annu Rev Biochem. 1998;67:509-544.

38. Chan FKM, Siegel RM, Zacharias D, et al. Fluorescence resonance energy transfer analysis of cell surface receptor interactions and signaling using spectral variants of the green fluorescent protein. Cytometry. 2001;44:361-368.

39. Wagner U, Hartel R, Matus A. Green fluorescent protein (GFP) as a marker in transgenic mice [abstract]. Eur J Neurosci. 1998;10:394.

40. Ikawa M, Kominami K, Yoshimura Y, Tanaka K, Nishimune Y, Okabe M. Green fluorescent protein as a marker in transgenic mice. Dev Growth Differ. 1995; 37:455-459.

41. Gagneten S, Le Y, Miller J, Sauer B. Brief expression of a GFP cre fusion gene in embryonic stem cells allows rapid retrieval of site-specific genomic deletions. Nucleic Acids Res. 1997;25:3326-3331.

42. Chiocchetti A, Tolosano E, Hirsch E, Silengo L, Altruda F. Green fluorescent protein as a reporter of gene expression in transgenic mice. Biochim Biophys Acta. 1997;1352:193-202.

43. Amsterdam A, Lin S, Moss LG, Hopkins N. Requirements for green fluorescent protein detection in transgenic zebrafish embryos. Gene. 1996;173:99-103.
44. Muldoon RR, Levy JP, Kain SR, Kitts PA, Link CJ. Tracking and quantitation of retroviral-mediated transfer using a completely humanized, red-shifted green fluorescent protein gene. Biotechniques. 1997;22:162.

45. Zhang G, Gurtu V, Kain SR. An enhanced green fluorescent protein allows sensitive detection of gene transfer in mammalian cells. Biochem Biophys Res Commun. 1996;227:707-711.

46. Gervaix A, West D, Leoni LM, Richman DD. WongStaal F, Corbeil J. A new reporter cell line to monitor HIV infection and drug susceptibility in vitro. Proc Natl Acad Sci USA. 1997;94:4653-4658.

47. Anderson MT, Tjioe IM, Lorincz MC, et al. Simultaneous fluorescence-activated cell sorter analysis of two distinct transcriptional elements within a single cell using engineered green fluorescent proteins. Proc Natl Acad Sci USA. 1996;93:8508-8511.

48. Niswender KD, Blackman SM, Rohde L, Magnuson MA, Piston DW. Quantitative imaging of green fluorescent protein in cultured-cells: comparison of microscopic techniques, use in fusion proteins and detection limits. J Microsc. 1995;180:109-116.

49. Patterson GH, Knobel SM, Sharif WD, Kain SR, Piston DW. Use of the green fluorescent protein and its mutants in quantitative fluorescence microscopy. Biophys J. 1997;73:2782-2790.

50. Shelby RD, Hahn KM, Sullivan KF. Dynamic elastic behavior of alpha-satellite DNA domains visualized in situ in living human cells. J Cell Biol. 1996;135:545-557.

51. Ariotti N, Hall TE, Rae J, et al. Modular detection of GFP-labeled proteins for rapid screening by electron microscopy in cells and organisms. Dev Cell. 2015;35:513-525.

52. Duwé S, De Zitter E, Gielen V, et al. Expression-enhanced fluorescent proteins based on enhanced green fluorescent protein for super-resolution microscopy. ACS Nano. 2015;9:9528-9541.

53. Contag $\mathrm{CH}$, Bachmann MH. Advances in vivo bioluminescence imaging of gene expression. Annu Rev Biomed Eng. 2002;4:235-260.

54. Mezzanotte L, van 't Root M, Karatas H, Goun EA, Lowik C. In vivo molecular bioluminescence imaging: new tools and applications. Trends Biotechnol. 2017;35:640-652.

55. Gould SJ, Subramani S. Firefly luciferase as a tool in molecular and cell biology. Anal Biochem. 1988;175:5-13.

56. Mueller-Klieser W, Walenta S, Paschen W, Kallinowski F, Vaupel P. Metabolic imaging in microregions of tumors and normal tissues with bioluminescence and photon counting. J Natl Cancer Inst. 1988;80:842-848.

57. Millar AJ, Short SR, Chua NH, Kay SA. A novel circadian phenotype based on firefly luciferase expression in transgenic plants. Plant Cell. 1992;4:1075-1087.

58. Maly FE, Urwyler A, Rolli HP, Dahinden CA, Deweck AL. A single-photon imaging system for the simultaneous quantitation of luminescent emissions from multiple samples. Anal Biochem. 1988;168:462-469.

59. Nussbaum A, Cohen A. Use of a bioluminescence gene reporter for the investigation of red-dependent and gam-dependent plasmid recombination in Escherichia coli K12. J Mol Biol. 1988;203:391-402.

60. Santos EB, Yeh R, Lee J, et al. Sensitive in vivo imaging of T cells using a membrane-bound Gaussia princeps luciferase. Nat Med. 2009;15:338-344.

61. Nakajima Y, Kobayashi K, Yamagishi K, Enomoto T, Ohmiya Y. CDNA cloning and characterization of a secreted luciferase from the luminous Japanese ostracod, Cypridina noctiluca. Biosci Biotechnol Biochem. 2004;68:565-570.

62. Maguire CA, Bovenberg MS, Crommentuijn MHW, et al. Triple bioluminescence imaging for in vivo monitoring of cellular processes. Mol Ther Nucleic Acids. 2013;2:e99.

63. Tannous BA, Kim DE, Fernandez JL, Weissleder R, Breakefield XO. Codonoptimized Gaussia luciferase cDNA for mammalian gene expression in culture and in vivo. Mol Ther. 2005;11:435-443.

64. Mezzanotte L, Aswendt M, Tennstaedt A, Hoeben R, Hoehn M, Lowik C. Evaluating reporter genes of different luciferases for optimized in vivo bioluminescence imaging of transplanted neural stem cells in the brain. Contrast Media Mol Imaging. 2013;8:505-513.

65. Gregor C, Gwosch KC, Sahl SJ, Hell SW. Strongly enhanced bacterial bioluminescence with the ilux operon for single-cell imaging. Proc Natl Acad Sci USA. 2018;115:962-967.

66. Zhao H, Doyle TC, Coquoz O, Kalish F, Rice BW, Contag CH. Emission spectra of bioluminescent reporters and interaction with mammalian tissue determine the sensitivity of detection in vivo. J Biomed Opt. 2005;10:41210.

67. Minn AJ, Kang Y, Serganova I, et al. Distinct organ-specific metastatic potential of individual breast cancer cells and primary tumors. J Clin Invest. 2005;115:44-55.

68. Minn AJ, Gupta GP, Siegel PM, et al. Genes that mediate breast cancer metastasis to lung. Nature. 2005;436:518-524.

69. Mayer-Kuckuk P, Doubrovin M, Bidaut L, et al. Molecular imaging reveals skeletal engraftment sites of transplanted bone marrow cells. Cell Transplant. 2006;15:75-82.

70. Mandl S, Schimmelpfennig C, Edinger M, Negrin RS, Contag CH. Understanding immune cell trafficking patterns via in vivo bioluminescence imaging. $J$ Cell Biochem Suppl. 2002;39:239-248.

71. Rabinovich BA, Ye Y, Etto T, et al. Visualizing fewer than 10 mouse T cells with an enhanced firefly luciferase in immunocompetent mouse models of cancer. Proc Natl Acad Sci USA. 2008;105:14342-14346. 
72. Kim JB, Urban K, Cochran E, et al. Non-invasive detection of a small number of bioluminescent cancer cells in vivo. PLoS One. 2010;5:e9364.

73. Edinger M, Cao YA, Verneris MR, Bachmann MH, Contag CH, Negrin RS. Revealing lymphoma growth and the efficacy of immune cell therapies using in vivo bioluminescence imaging. Blood. 2003;101:640-648.

74. Luker KE, Mihalko LA, Schmidt BT, et al. In vivo imaging of ligand receptor binding with Gaussia luciferase complementation. Nat Med. 2011;18:172-177.

75. Foucault ML, Thomas L, Goussard S, Branchini BR, Grillot-Courvalin C. In vivo bioluminescence imaging for the study of intestinal colonization by Escherichia coli in mice. Appl Environ Microbiol. 2010;76:264-274.

76. De A, Ray P, Loening AM, Gambhir SS. BRET3: a red-shifted bioluminescence resonance energy transfer (BRET)-based integrated platform for imaging protein-protein interactions from single live cells and living animals. FASEB J. 2009; 23:2702-2709.

77. Xu T, Close D, Handagama W, Marr E, Sayler G, Ripp S. The expanding toolbox of in vivo bioluminescent imaging. Front Oncol. 2016;6:150.

78. Nakajima Y, Yamazaki T, Nishii S, et al. Enhanced beetle luciferase for highresolution bioluminescence imaging. PLoS One. 2010;5:e10011.

79. Xu T, Ripp S, Sayler GS, Close DM. Expression of a humanized viral 2amediated lux operon efficiently generates autonomous bioluminescence in human cells. PLoS One. 2014;9:e96347.

80. Villalobos V, Naik S, Bruinsma M, et al. Dual-color click beetle luciferase heteroprotein fragment complementation assays. Chem Biol. 2010;17:1018-1029.

81. Kocher B, Piwnica-Worms D. Illuminating cancer systems with genetically engineered mouse models and coupled luciferase reporters in vivo. Cancer Discov. 2013;3:616-629.

82. Prescher JA, Contag $\mathrm{CH}$. Guided by the light: visualizing biomolecular processes in living animals with bioluminescence. Curr Opin Chem Biol. 2010;14:80-89.

83. Chievitz OBN, de Hevesy G. Radioactive indicators in the study of phosphorous metabolism in rats. Nature. 1935;1935:754.

84. Gest $\mathrm{H}$. The early history of P-32 as a radioactive tracer in biochemical research: a personal memoir. Biochem Mol Biol Educ. 2005;33:159-164.

85. Blasberg RG, Tjuvajev JG. Herpes simplex virus thymidine kinase as a marker/ reporter gene for PET imaging of gene therapy. Q J Nucl Med. 1999;43:163-169.

86. Tjuvajev JG, Chen SH, Joshi A, et al. Imaging adenoviral-mediated herpes virus thymidine kinase gene transfer and expression in vivo. Cancer Res. 1999;59:5186-5193.

87. Tjuvajev JG, Joshi A, Callegari J, et al. A general approach to the non-invasive imaging of transgenes using cis-linked herpes simplex virus thymidine kinase. Neoplasia. 1999;1:315-320.

88. Gambhir SS, Herschman HR, Cherry SR, et al. Imaging transgene expression with radionuclide imaging technologies. Neoplasia. 2000;2:118-138.

89. Jacobs A, Tjuvajev JG, Dubrovin M, et al. Positron emission tomography-based imaging of transgene expression mediated by replication-conditional, oncolytic herpes simplex virus type 1 mutant vectors in vivo. Cancer Res. 2001;61:2983-2995.

90. Green LA, Nguyen K, Berenji B, et al. A tracer kinetic model for F-18-FHBG for quantitating herpes simplex virus type 1 thymidine kinase reporter gene expression in living animals using PET. J Nucl Med. 2004;45:1560-1570.

91. Gambhir SS, Bauer E, Black ME, et al. A mutant herpes simplex virus type 1 thymidine kinase reporter gene shows improved sensitivity for imaging reporter gene expression with positron emission tomography. Proc Natl Acad Sci USA. 2000;97:2785-2790.

92. Gambhir SS, Barrio JR, Wu L, et al. Imaging of adenoviral-directed herpes simplex virus type 1 thymidine kinase reporter gene expression in mice with radiolabeled ganciclovir. $J$ Nucl Med. 1998;39:2003-2011.

93. Iyer M, Barrio JR, Namavari M, et al. 8-[F-18]fluoropenciclovir: an improved reporter probe for imaging HSV1-tk reporter gene expression in vivo using PET. J Nucl Med. 2001;42:96-105.

94. Yaghoubi S, Barrio JR, Dahlbom M, et al. Human pharmacokinetic and dosimetry studies of $\left[{ }^{18} \mathrm{~F}\right] \mathrm{FHBG}$ : a reporter probe for imaging herpes simplex virus type-1 thymidine kinase reporter gene expression. J Nucl Med. 2001;42:12251234.

95. Alauddin MM, Shahinian A, Gordon EM, Bading JR, Conti PS. Preclinical evaluation of the penciclovir analog 9-(4-[ $\left.{ }^{18} \mathrm{~F}\right]$ fluoro-3-hydroxymethylbutyl) guanine for in vivo measurement of suicide gene expression with PET. $J$ Nucl Med. 2001;42:1682-1690.

96. Tjuvajev JG, Doubrovin M, Akhurst T, et al. Comparison of radiolabeled nucleoside probes (FIAU, FHBG, and FHPG) for PET imaging of HSV1-tk gene expression. J Nucl Med. 2002;43:1072-1083.

97. Sweeney DC, Johnston GS. Radioiodine therapy for thyroid cancer. Endocrinol Metab Clin North Am. 1995;24:803-839.

98. Groot-Wassink T, Aboagye EO, Glaser M, Lemoine NR, Vassaux G. Adenovirus biodistribution and noninvasive imaging of gene expression in vivo by positron emission tomography using human sodium/iodide symporter as reporter gene. Hum Gene Ther. 2002;13:1723-1735.
99. Frey P, Townsend D, Flattet A, et al. Tomographic imaging of the human thyroid using I-124. J Clin Endocrinol Metab. 1986;63:918-927.

100. Frey P, Townsend D, Christin A, et al. Tomographic imaging of the human thyroid using I-124 [abstract]. J Nucl Med. 1986;27(suppl):909.

101. Hingorani M, Spitzweg C, Vassaux G, et al. The biology of the sodium iodide symporter and its potential for targeted gene delivery. Curr Cancer Drug Targets. 2010;10:242-267.

102. Minn I, Menezes ME, Sarkar S, et al. Molecular-genetic imaging of cancer. $A d v$ Cancer Res. 2014;124:131-169.

103. Ponomarev V, Doubrovin M, Serganova I, et al. A novel triple-modality reporter gene for whole-body fluorescent, bioluminescent, and nuclear noninvasive imaging. Eur J Nucl Med Mol Imaging. 2004;31:740-751.

104. Doubrovin M, Ponomarev V, Serganova I, et al. Development of a new reporter gene system: dsRed/xanthine phosphoribosyltransferase-xanthine for molecular imaging of processes behind the intact blood-brain barrier. Mol Imaging. 2003;2:93-112.

105. Ray P, De A, Min JJ, Tsien RY, Gambhir SS. Imaging tri-fusion multimodality reporter gene expression in living subjects. Cancer Res. 2004;64:1323-1330.

106. Lee HW, Jeon $\mathrm{YH}$, Hwang $\mathrm{MH}$, et al. Dual reporter gene imaging for tracking macrophage migration using the human sodium iodide symporter and an enhanced firefly luciferase in a murine inflammation model. Mol Imaging Biol. 2013;15:703-712.

107. Kesarwala AH, Prior JL, Sun JW, Harpstrite SE, Sharma V, Piwnica-Worms D. Second-generation triple reporter for bioluminescence, micro-positron emission tomography, and fluorescence imaging. Mol Imaging. 2006;5:465-474.

108. Massoud TF, Gambhir SS. Molecular imaging in living subjects: seeing fundamental biological processes in a new light. Genes Dev. 2003;17:545-580.

109. Chen R, Parry JJ, Akers WJ, et al. Multimodality imaging of gene transfer with a receptor-based reporter gene. J Nucl Med. 2010;51:1456-1463.

110. Zhang F, Zhu L, Liu G, et al. Multimodality imaging of tumor response to Doxil. Theranostics. 2011;1:302-309.

111. Burke BP, Cawthorne C, Archibald SJ. Multimodal nanoparticle imaging agents: design and applications. Philos Trans A Math Phys Eng Sci. 2017;375: 20170261.

112. Mayer-Kuckuk P, Banerjee D, Malhotra S, et al. Cells exposed to antifolates show increased cellular levels of proteins fused to dihydrofolate reductase: a method to modulate gene expression. Proc Natl Acad Sci USA. 2002;99:3400-3405.

113. Liang Q, Gotts J, Satyamurthy N, et al. Noninvasive, repetitive, quantitative measurement of gene expression from a bicistronic message by positron emission tomography, following gene transfer with adenovirus. Mol Ther. 2002;6:73-82.

114. Che J, Doubrovin M, Serganova I, Ageyeva L, Zanzonico P, Blasberg R. hNISIRES-eGFP dual reporter gene imaging. Mol Imaging. 2005;4:128-136.

115. Bhatnagar A, Gabrielson K, Fisher PB, Pomper MG. Molecular-genetic imaging of prostate cancer [abstract]. J Nucl Med. 2013;54(suppl):4.

116. Pasleau F, Tocci MJ, Leung F, Kopchick JJ. Growth-hormone gene-expression in eukaryotic cells directed by the Rous-sarcoma virus long terminal repeat or cytomegalovirus immediate-early promoter. Gene. 1985;38:227-232.

117. Oellig C, Seliger B. Gene-transfer into brain-tumor cell-lines: reporter geneexpression using various cellular and viral promoters. J Neurosci Res. 1990;26: 390-396.

118. Tjuvajev J, Blasberg R, Luo X, Zheng LM, King I, Bermudes D. Salmonellabased tumor-targeted cancer therapy: tumor amplified protein expression therapy (TAPET) for diagnostic imaging. J Control Release. 2001;74:313-315.

119. Pantuck AJ, Berger F, Zisman A, et al. CL1-SR39: a noninvasive molecular imaging model of prostate cancer suicide gene therapy using positron emission tomography. J Urol. 2002;168:1193-1198.

120. Bengel FM, Anton M, Avril N, et al. Uptake of radiolabeled 2 '-fluoro- 2 '-deoxy5-iodo-1-beta-D-arabinofuranosyluracil in cardiac cells after adenoviral transfer of the herpesvirus thymidine kinase gene: the cellular basis for cardiac gene imaging. Circulation. 2000;102:948-950.

121. Bentley NJ, Eisen T, Goding CR. Melanocyte-specific expression of the human tyrosinase promoter: activation by the microphthalmia gene-product and role of the initiator. Mol Cell Biol. 1994;14:7996-8006.

122. Fujiwara T, Urata Y, Tanaka N. Telomerase-specific oncolytic virotherapy for human cancer with the hTERT promoter. Curr Cancer Drug Targets. 2007;7:191-201.

123. Bhang HEC, Gabrielson KL, Laterra J, Fisher PB, Pomper MG. Tumor-specific imaging through progression elevated gene-3 promoter-driven gene expression. Nat Med. 2011;17:123-129.

124. Qin JY, Zhang L, Clift KL, et al. Systematic comparison of constitutive promoters and the doxycycline-inducible promoter. PLoS One. 2010;5:e10611.

125. Brooks AR, Harkins RN, Wang PY, Qian HS, Liu PX, Rubanyi GM. Transcriptional silencing is associated with extensive methylation of the CMV promoter following adenoviral gene delivery to muscle. J Gene Med. 2004;6:395-404.

126. Gobuty AHRR, Barth RF. Organ distribution of ${ }^{99 \mathrm{~m}} \mathrm{Tc}-$ and ${ }^{51} \mathrm{Cr}$-labeled autologous peripheral blood lymphocytes in rabbits. J Nucl Med. 1977;18:141-146. 
127. Papierniak CKBR, Kretschmer RR, Gotoff SP, Colombetti LG. Technetium99m labeling of human monocytes for chemotactic studies. J Nucl Med. 1976;17: 988-992.

128. Korf J, Veenma-van der Duin L, Brinkman-Medema R, Niemarkt A, de Leij LF. Divalent cobalt as a label to study lymphocyte distribution using PET and SPECT. J Nucl Med. 1998;39:836-841.

129. Rannie GHTM, Ford WL. An experimental comparison of radioactive labels with potential application to lymphocyte migration studies in patients. Clin Exp Immunol. 1977;29:509-514.

130. Adonai N, Walsh J, Iyer M, et al. Ex vivo cell labeling with ${ }^{64} \mathrm{Cu}$-pyruvaldehyde-bis(N4-methylthiosemicarbazone) for imaging cell trafficking in mice with positron-emission tomography. Proc Natl Acad Sci USA. 2002;99:3030-3035.

131. Hagani ABRI, Tan C, Krause A, Sadelain M. Activation conditions determine susceptibility of murine primary T-lymphocytes to retroviral infection. J Gene Med. 1999;1:341-351.

132. Gallardo HF, Tan C, Ory D, Sadelain M. Recombinant retroviruses pseudotyped with the vesicular stomatitis virus $\mathrm{G}$ glycoprotein mediate both stable gene transfer and pseudotransduction in human peripheral blood lymphocytes. Blood. 1997;90: 952-957.

133. Rooney CMSC, Ng CY, Loftin S, et al. Use of gene-modified virus-specific T lymphocytes to control Epstein-Barr-virus-related lymphoproliferation. Lancet. 1995;345:9-13.

134. Verzeletti S, Marktel S, Nobili N, Ciceri F, Traversari C, Bordignon C. Herpes simplex virus thymidine kinase gene transfer for controlled graft-versus-host disease and graft-versus-leukemia: clinical follow-up and improved new vectors. Hum Gene Ther. 1998;9:2243-2251.

135. Bonini C, Verzeletti S, Servida P, et al. HSV-TK gene transfer into donor lymphocytes for control of allogeneic graft-versus-leukemia. Science. 1997;276:1719-1724.

136. Hardy J, Bachmann MH, Negrin RS, Fathman CG, Contag CH. Bioluminescence imaging of lymphocyte trafficking in vivo. Exp Hematol. 2001;29:1353-1360.

137. Zhang W, Harris SE, Contag PR, Stevenson DK, Contag CH. Rapid in vivo functional analysis of transgenes in mice using whole body imaging of luciferase expression. Transgenic Res. 2001;10:423-434.

138. Koehne G, Doubrovin M, Doubrovina E, et al. Serial in vivo imaging of the targeted migration of human HSV-TK-transduced antigen-specific lymphocytes. Nat Biotechnol. 2003;21:405-413.

139. Chewning JH, Dugger KJ, Chaudhuri TR, Zinn KR, Weaver CT. Bioluminescence-based visualization of CD4 $\mathrm{T}$ cell dynamics using a $\mathrm{T}$ lineage-specific luciferase transgenic model. BMC Immunol. 2009;10:44.

140. Lee HW, Yoon SY, Singh TD, et al. Tracking of dendritic cell migration into lymph nodes using molecular imaging with sodium iodide symporter and enhanced firefly luciferase genes. Sci Rep. 2015;5:9865.

141. Choi YJ, Oh SG, Singh TD, et al. Visualization of the biological behavior of tumor-associated macrophages in living mice with colon cancer using multimodal optical reporter gene imaging. Neoplasia. 2016;18:133-141.

142. Sun N, Lee A, Wu JC. Long term non-invasive imaging of embryonic stem cells using reporter genes. Nat Protoc. 2009;4:1192-1201.

143. Pei Z, Zeng J, Song YF, et al. In vivo imaging to monitor differentiation and therapeutic effects of transplanted mesenchymal stem cells in myocardial infarction. Sci Rep. 2017;7:6296.

144. Lee HW, Gangadaran P, Kalimuthu S, Ahn BC. Advances in molecular imaging strategies for in vivo tracking of immune cells. BioMed Res Int. 2016;2016: 1946585.

145. Willhauck MJ, Samani BS, Klutz K, et al. alpha-fetoprotein promoter-targeted sodium iodide symporter gene therapy of hepatocellular carcinoma. Gene Ther. 2008; 15:214-223.

146. Chen L, Altmann A, Mier W, et al. Radioiodine therapy of hepatoma using targeted transfer of the human sodium/iodide symporter gene. J Nucl Med. 2006; 47:854-862.

147. Pouliot F, Karanikolas BDW, Johnson M, et al. In vivo imaging of intraprostatic-specific gene transcription by PET. J Nucl Med. 2011;52:784-791.

148. Jiang ZK, Sato M, Wei LH, Kao CH, Wu L. Androgen-independent molecular imaging vectors to detect castration-resistant and metastatic prostate cancer. Cancer Res. 2011;71:6250-6260.

149. Hallahan DE, Qu SM, Geng L, et al. Radiation-mediated control of drug delivery. Am J Clin Oncol. 2001;24:473-480.

150. Ahn BC, Ronald JA, Kim YI, et al. Potent, tumor-specific gene expression in an orthotopic hepatoma rat model using a Survivin-targeted, amplifiable adenoviral vector. Gene Ther. 2011;18:606-612.

151. Kishimoto H, Kojima T, Watanabe Y, et al. In vivo imaging of lymph node metastasis with telomerase-specific replication-selective adenovirus. Nat Med. 2006;12:1213-1219.

152. Bhang HE, Pomper MG. Cancer imaging: gene transcription-based imaging and therapeutic systems. Int J Biochem Cell Biol. 2012;44:684-689.
153. Doubrovin M, Ponomarev V, Beresten T, et al. Imaging transcriptional regulation of p53-dependent genes with positron emission tomography in vivo. Proc Natl Acad Sci USA. 2001;98:9300-9305.

154. Ponomarev V, Doubrovin M, Lyddane C, et al. Imaging TCR-dependent NFATmediated T-cell activation with positron emission tomography in vivo. Neoplasia. 2001;3:480-488.

155. Patel MR, Chang YF, Chen IY, et al. Longitudinal, noninvasive imaging of T-cell effector function and proliferation in living subjects. Cancer Res. 2010; 70:10141-10149.

156. Serganova I, Doubrovin M, Vider J, et al. Molecular imaging of temporal dynamics and spatial heterogeneity of hypoxia-inducible factor-1 signal transduction activity in tumors in living mice. Cancer Res. 2004;64:6101-6108.

157. Brader P, Riedl CC, Woo Y, et al. Imaging of hypoxia-driven gene expression in an orthotopic liver tumor model. Mol Cancer Ther. 2007;6:2900-2908.

158. Serganova I, Cohen IJ, Vemuri K, et al. LDH-A regulates the tumor microenvironment via HIF-signaling and modulates the immune response. PLoS One. 2018; 13:e0203965.

159. Gross S, Piwnica-Worms D. Real-time imaging of ligand-induced IKK activation in intact cells and in living mice. Nat Methods. 2005;2:607-614.

160. Moroz E, Carlin S, Dyomina K, et al. Real-time imaging of HIF-1alpha stabilization and degradation. PLoS One. 2009;4:e5077.

161. Che J, Doubrovin M, Serganova I, et al. HSP70-inducible hNIS-IRESeGFP reporter imaging: response to heat shock. Mol Imaging. 2007;6:404416.

162. Doubrovin M, Che JT, Serganova I, et al. Monitoring the induction of heat shock factor 1 /heat shock protein 70 expression following 17-allylamino-demethoxygeldanamycin treatment by positron emission tomography and optical reporter gene imaging. Mol Imaging. 2012;11:67-76.

163. Kang Y, He W, Tulley S, et al. Breast cancer bone metastasis mediated by the Smad tumor suppressor pathway. Proc Natl Acad Sci USA. 2005;102:1390913914.

164. Serganova I, Moroz E, Vider J, et al. Multimodality imaging of TGFbeta signaling in breast cancer metastases. FASEB J. 2009;23:2662-2672.

165. Korpal M, Yan J, Lu X, Xu S, Lerit DA, Kang Y. Imaging transforming growth factor-beta signaling dynamics and therapeutic response in breast cancer bone metastasis. Nat Med. 2009;15:960-966.

166. Nyati S, Schinske K, Ray D, Nyati MK, Ross BD, Rehemtulla A. Molecular imaging of TGFbeta-induced Smad2/3 phosphorylation reveals a role for receptor tyrosine kinases in modulating TGFbeta signaling. Clin Cancer Res. 2011;17:7424-7439.

167. Aalipour A, Chuang H-Y, Murty S, et al. Engineered immune cells as highly sensitive cancer diagnostics. Nat Biotechnol. 2019;37:531-539.

168. Choudhury PS, Gupta M. Differentiated thyroid cancer theranostics: radioiodine and beyond. Br J Radiol. 2018;91:20180136.

169. Ravera S, Reyna-Neyra A, Ferrandino G, Amzel LM, Carrasco N. The sodium/ iodide symporter (NIS): molecular physiology and preclinical and clinical applications. Annu Rev Physiol. 2017;79:261-289.

170. Smanik PA, Liu Q, Furminger TL, et al. Cloning of the human sodium iodide symporter. Biochem Biophys Res Commun. 1996;226:339-345.

171. Mandell RB, Mandell LZ, Link CJ. Radioisotope concentrator gene therapy using the sodium/iodide symporter gene. Cancer Res. 1999;59:661-668.

172. Dingli D, Russell SJ, Morris JC. In vivo imaging and tumor therapy with the sodium iodide symporter. J Cell Biochem. 2003;90:1079-1086.

173. Shin JH, Chung JK, Kang JH, et al. Feasibility of sodium/iodide symporter gene as a new imaging reporter gene: comparison with HSV1-tk. Eur J Nucl Med Mol Imaging. 2004;31:425-432.

174. Haberkorn U. Gene therapy with sodium/iodide symporter in hepatocarcinoma. Exp Clin Endocrinol Diabetes. 2001;109:60-62.

175. Urnauer S, Muller AM, Schug C, et al. EGFR-targeted nonviral NIS gene transfer for bioimaging and therapy of disseminated colon cancer metastases. Oncotarget. 2017;8:92195-92208.

176. Jiang HL, Schmit N, Koenen A, et al. cGMP synthesis of sodium-iodide symporter (NIS) probe F-18-tetrafluoroborate (F-18-TFB) and biodistribution in healthy male and female human subjects [abstract]. J Nucl Med. 2017; 58(suppl 1):682.

177. Moroz MA, Serganova I, Zanzonico P, et al. Imaging hNET reporter gene expression with ${ }^{124}$ I-MIBG. J Nucl Med. 2007;48:827-836.

178. Zhang H, Huang R, Cheung NK, et al. Imaging the norepinephrine transporter in neuroblastoma: a comparison of $\left[{ }^{18} \mathrm{~F}\right]-\mathrm{MFBG}$ and ${ }^{123} \mathrm{I}-\mathrm{MIBG}$. Clin Cancer Res. 2014;20:2182-2191.

179. Doubrovin MM, Doubrovina ES, Zanzonico P, Sadelain M, Larson SM, O'Reilly RJ. In vivo imaging and quantitation of adoptively transferred human antigen-specific $\mathrm{T}$ cells transduced to express a human norepinephrine transporter gene. Cancer Res. 2007;67:11959-11969. 
180. MacLaren DC, Gambhir SS, Satyamurthy N, et al. Repetitive, non-invasive imaging of the dopamine $\mathrm{D} 2$ receptor as a reporter gene in living animals. Gene Ther. 1999;6:785-791.

181. Yaghoubi SS, Wu L, Liang Q, et al. Direct correlation between positron emission tomographic images of two reporter genes delivered by two distinct adenoviral vectors. Gene Ther. 2001;8:1072-1080.

182. Price LA, Kajkowski EM, Hadcock JR, Ozenberger BA, Pausch MH. Functional coupling of a mammalian somatostatin receptor to the yeast pheromone response pathway. Mol Cell Biol. 1995;15:6188-6195.

183. Zinn KR, Chaudhuri TR. The type 2 human somatostatin receptor as a platform for reporter gene imaging. Eur J Nucl Med Mol Imaging. 2002;29:388-399.

184. Rogers BE, Chaudhuri TR, Reynolds PN, Della Manna D, Zinn KR. Non-invasive gamma camera imaging of gene transfer using an adenoviral vector encoding an epitope-tagged receptor as a reporter. Gene Ther. 2003;10:105-114.

185. Zhang H, Moroz MA, Serganova I, et al. Imaging expression of the human somatostatin receptor subtype-2 reporter gene with Ga-68-DOTATOC. J Nucl Med. 2011;52:123-131.

186. Liang Q, Satyamurthy N, Barrio JR, et al. Noninvasive, quantitative imaging in living animals of a mutant dopamine D2 receptor reporter gene in which ligand binding is uncoupled from signal transduction. Gene Ther. 2001;8:1490-1498.

187. Vedvyas Y, Shevlin E, Zaman M, et al. Longitudinal PET imaging demonstrates biphasic CAR T cell responses in survivors. JCI Insight. 2016;1:e90064.

188. Moroz MA, Zhang H, Lee J, et al. Comparative analysis of T cell imaging with human nuclear reporter genes. J Nucl Med. 2015;56:1055-1060.

189. Likar Y, Zurita J, Dobrenkov K, et al. A new pyrimidine-specific reporter gene: a mutated human deoxycytidine kinase suitable for PET during treatment with acycloguanosine-based cytotoxic drugs. J Nucl Med. 2010;51:1395-1403.

190. Campbell DO, Yaghoubi SS, Su Y, et al. Structure-guided engineering of human thymidine kinase 2 as a positron emission tomography reporter gene for enhanced phosphorylation of non-natural thymidine analog reporter probe. J Biol Chem. 2012;287:446-454

191. Gil JS, Machado HB, Campbell DO, et al. Application of a rapid, simple, and accurate adenovirus-based method to compare PET reporter gene/PET reporter probe systems. Mol Imaging Biol. 2013;15:273-281.

192. Lee JT, Zhang H, Moroz MA, et al. Comparative analysis of human nucleoside kinase-based reporter systems for PET imaging. Mol Imaging Biol. 2017;19:100-108.

193. Rajasekaran AK, Anilkumar G, Christiansen JJ. Is prostate-specific membrane antigen a multifunctional protein? Am J Physiol Cell Physiol. 2005;288:C975-C981.

194. Chen Y, Dhara S, Banerjee SR, et al. A low molecular weight PSMA-based fluorescent imaging agent for cancer. Biochem Biophys Res Commun. 2009;390:624-629.

195. Banerjee SR, Pullambhatla M, Byun Y, et al. Sequential SPECT and optical imaging of experimental models of prostate cancer with a dual modality inhibitor of the prostate-specific membrane antigen. Angew Chem Int Ed Engl. 2011;50: 9167-9170.

196. Kommidi H, Guo H, Nurili F, et al. ${ }^{18} \mathrm{~F}$-positron emitting/trimethine cyaninefluorescent contrast for image-guided prostate cancer management. J Med Chem. 2018;61:4256-4262.

197. Castanares MA, Mukherjee A, Chowdhury WH, et al. Evaluation of prostatespecific membrane antigen as an imaging reporter. J Nucl Med. 2014;55:805-811.

198. Kaittanis C, Andreou C, Hieronymus H, et al. Prostate-specific membrane antigen cleavage of vitamin B9 stimulates oncogenic signaling through metabotropic glutamate receptors. J Exp Med. 2018;215:159-175.

199. Haywood T, Beinat C, Gowrishankar G, et al. Positron emission tomography reporter gene strategy for use in the central nervous system. Proc Natl Acad Sci USA. 2019;116:11402-11407.

200. Witney TH, James ML, Shen B, et al. PET imaging of tumor glycolysis downstream of hexokinase through noninvasive measurement of pyruvate kinase M2. Sci Transl Med. 2015;7:310ra169.

201. Beinat C, Haywood T, Chen YS, et al. The utility of $\left[{ }^{18}\right.$ F $]$ DASA-23 for molecular imaging of prostate cancer with positron emission tomography. Mol Imaging Biol. 2018;20:1015-1024.

202. Wei LH, Olafsen T, Radu C, et al. Engineered antibody fragments with infinite affinity as reporter genes for PET imaging. J Nucl Med. 2008;49:1828-1835.

203. Serganova I, Ponomarev V, Blasberg R. Human reporter genes: potential use in clinical studies. Nucl Med Biol. 2007;34:791-807.

204. Cohen B, Dafni H, Meir G, Harmelin A, Neeman M. Ferritin as an endogenous MRI reporter for noninvasive imaging of gene expression in C6 glioma tumors. Neoplasia. 2005;7:109-117.

205. Gilad AA, Ziv K, McMahon MT, van Zijl PCM, Neeman M, Bulte JWM. MRI reporter genes. J Nucl Med. 2008;49:1905-1908.

206. James ML, Gambhir SS. A molecular imaging primer: modalities, imaging agents, and applications. Physiol Rev. 2012;92:897-965

207. Gilad AA, McMahon MT, Walczak P, et al. Artificial reporter gene providing MRI contrast based on proton exchange. Nat Biotechnol. 2007;25:217-219.
208. Vande Velde G, Himmelreich U, Neeman M. Reporter gene approaches for mapping cell fate decisions by MRI: promises and pitfalls. Contrast Media Mol Imaging. 2013;8:424-431.

209. Yang C, Tian R, Liu T, Liu G. MRI reporter genes for noninvasive molecular imaging. Molecules. 2016;21:E580.

210. Patrick PS, Hammersley J, Loizou L, et al. Dual-modality gene reporter for in vivo imaging. Proc Natl Acad Sci USA. 2014;111:415-420.

211. Wu MR, Liu HM, Lu CW, et al. Organic anion-transporting polypeptide $1 \mathrm{~B} 3$ as a dual reporter gene for fluorescence and magnetic resonance imaging. FASEB J. 2018;32:1705-1715.

212. Nanda D, Vogels R, Havenga M, Avezaat CJ, Bout A, Smitt PS. Treatment of malignant gliomas with a replicating adenoviral vector expressing herpes simplex virus-thymidine kinase. Cancer Res. 2001;61:8743-8750.

213. Maleniak TC, Darling JL, Lowenstein PR, Castro MG. Adenovirus-mediated expression of HSV1-TK or Fas ligand induces cell death in primary human glioma-derived cell cultures that are resistant to the chemotherapeutic agent CCNU. Cancer Gene Ther. 2001;8:589-598.

214. Cowsill C, Southgate TD, Morrissey G, et al. Central nervous system toxicity of two adenoviral vectors encoding variants of the herpes simplex virus type 1 thymidine kinase: reduced cytotoxicity of a truncated HSV1-TK. Gene Ther. 2000;7:679-685.

215. Windeatt S, Southgate TD, Dewey RA, et al. Adenovirus-mediated herpes simplex virus type-1 thymidine kinase gene therapy suppresses oestrogeninduced pituitary prolactinomas. J Clin Endocrinol Metab. 2000;85:1296-1305.

216. Klatzmann D, Herson S, Cherin P, et al. Gene therapy for metastatic malignant melanoma: evaluation of tolerance to intratumoral injection of cells producing recombinant retroviruses carrying the herpes simplex virus type 1 thymidine kinase gene, to be followed by ganciclovir administration. Hum Gene Ther. 1996; 7:255-267.

217. Nanda D, Vogels R, Havenga M, Avezaat CJ, Bout A, Smitt PS. Treatment of malignant gliomas with a replicating adenoviral vector expressing herpes simplex virus-thymidine kinase. Cancer Res. 2001;61:8743-8750.

218. Maleniak TC, Darling JL, Lowenstein PR, Castro MG. Adenovirus-mediated expression of HSV1-TK or Fas ligand induces cell death in primary human glioma-derived cell cultures that are resistant to the chemotherapeutic agent CCNU. Cancer Gene Ther. 2001;8:589-598.

219. Fecci PE, Gromeier M, Sampson JH. Viruses in the treatment of brain tumors. Neuroimaging Clin N Am. 2002;12:553-570.

220. Jacobs A, Voges J, Reszka R, et al. Positron-emission tomography of vectormediated gene expression in gene therapy for gliomas. Lancet. 2001;358:727-729.

221. Dempsey MF, Wyper D, Owens J, et al. Assessment of ${ }^{123}$ I-FIAU imaging of herpes simplex viral gene expression in the treatment of glioma. Nucl Med Commun. 2006;27:611-617.

222. Peñuelas I, Mazzolini G, Boan JF, et al. Positron emission tomography imaging of adenoviral-mediated transgene expression in liver cancer patients. Gastroenterology. 2005;128:1787-1795.

223. Yaghoubi SS, Jensen MC, Satyamurthy N, et al. Noninvasive detection of therapeutic cytolytic $\mathrm{T}$ cells with ${ }^{18} \mathrm{~F}$-FHBG PET in a patient with glioma. Nat Clin Pract Oncol. 2009;6:53-58.

224. Keu KV, Witney TH, Yaghoubi S, et al. Reporter gene imaging of targeted T cell immunotherapy in recurrent glioma. Sci Transl Med. 2017;9:eaag2196.

225. Dotti G, Tian M, Savoldo B, et al. Repetitive noninvasive monitoring of HSV1tk-expressing $\mathrm{T}$ cells intravenously infused into nonhuman primates using positron emission tomography and computed tomography with F-18-FEAU. Mol Imaging. 2009;8:230-237.

226. Templin C, Zweigerdt R, Schwanke K, et al. Transplantation and tracking of human-induced pluripotent stem cells in a pig model of myocardial infarction: assessment of cell survival, engraftment, and distribution by hybrid single photon emission computed tomography/computed tomography of sodium iodide symporter transgene expression. Circulation. 2012;126:430-439.

227. Eyquem J, Mansilla-Soto J, Giavridis T, et al. Targeting a CAR to the TRAC locus with CRISPR/Cas9 enhances tumour rejection. Nature. 2017;543:113.

228. Boyiadzis MM, Dhodapkar MV, Brentjens RJ, et al. Chimeric antigen receptor (CAR) $\mathrm{T}$ therapies for the treatment of hematologic malignancies: clinical perspective and significance. J Immunother Cancer. 2018;6:137.

229. D'Aloia MM, Zizzari IG, Sacchetti B, Pierelli L, Alimandi M. CAR-T cells: the long and winding road to solid tumors. Cell Death Dis. 2018;9:282.

230. Keu KV, Witney TH, Yaghoubi S, et al. Reporter gene imaging of targeted T cell immunotherapy in recurrent glioma. Sci Transl Med. 2017;9:eaag2196.

231. Zonari E, Desantis G, Petrillo C, et al. Efficient ex vivo engineering and expansion of highly purified human hematopoietic stem and progenitor cell populations for gene therapy. Stem Cell Reports. 2017;8:977-990.

232. Kotterman MA, Chalberg TW, Schaffer DV. Viral vectors for gene therapy: translational and clinical outlook. Annu Rev Biomed Eng. 2015;17:63-89. 